\title{
Four new species of Hydnellum (Thelephorales, Basidiomycota) with a note on Sarcodon illudens
}

\author{
J. Nitare ${ }^{1}$, A.M. Ainsworth ${ }^{2}$, E. Larsson ${ }^{3,4}$, D. Parfitt ${ }^{5}$, L.M. Suz ${ }^{2}$, S. Svantesson ${ }^{3,4}$, K.-H. Larsson ${ }^{4,6 *}$ \\ ${ }^{1}$ Skogsstyrelsen, SE-551 83 Jönköping, Sweden \\ ${ }^{2} J$ Jodrell Laboratory, Royal Botanic Gardens, Kew, Richmond, Surrey, TW9 3DS UK \\ ${ }^{3}$ Department of Biological and Environmental Sciences, University of Gothenburg, P.O. Box 461, SE-405 30 Göteborg, Sweden \\ ${ }^{4}$ Gothenburg Global Biodiversity Centre, P.O. Box 461, SE-405 30 Göteborg, Sweden \\ ${ }^{5}$ Cardiff School of Biosciences, Cardiff University, Cardiff, CF10 3AX UK \\ ${ }^{6}$ Natural History Museum, University of Oslo, P.O. Box 1172 Blindern, NO-0318 Oslo, Norway
}

*Corresponding author: k.h.larsson@nhm.uio.no

\section{Key words:}

conservation

ECM fungi

ectomycorrhizal fungi

new taxa

stipitate hydnoid

tooth fungi

\begin{abstract}
Four new Hydnellum species are described. Hydnellum roseoviolaceum sp. nov. grows in dry pine heaths on acidic, sandy soil. It is close to $H$. fuligineoviolaceum, another pine-associated species, but differs by smaller spores, an initially rose-coloured instead of violet flesh in fresh basidiomata and a mild taste. Hydnellum scabrosellum sp. nov. grows in coniferous forests on calcareous soil. It shares a general morphology with $H$. scabrosum, which also is its closest relative. It differs by having smaller and slenderer basidiomata and by the yellowish ochraceous colour of flesh and spines in dried specimens compared to the whitish or reddish brown colour seen in $H$. scabrosum. Hydnellum fagiscabrosum sp. nov. is another species with morphological and phylogenetic affinities to $H$. scabrosum. However, it is associated with trees from Fagales whereas $\mathrm{H}$. scabrosum is associated with Pinaceae. Hydnellum nemorosum $s p$. nov. is yet another species that associates with broadleaved trees. It seems to be a rare species, morphologically reminiscent of $\mathrm{H}$. fuligineoviolaceum, $\mathrm{H}$. ioeides and $\mathrm{H}$. scabrosum, but it is phylogenetically close to $\mathrm{H}$. fennicum. Sequences from the type specimens of $H$. glaucopus, $H$. lepidum, $H$. scabrosum, Sarcodon illudens and $S$. regalis are included in the analyses. Specimens given the provisional name "Sarcodon pseudoglaucopus" in Sweden are now shown to be referable to S. illudens. The analyses further showed that S. illudens is close to H. lepidum. The new combination Hydnellum illudens is proposed. Sarcodon regalis and $H$. lepidum are shown to be conspecific and, although their basionyms were simultaneously published, the name $S$. regalis was only validated in a later publication. Hydnellum lepidum therefore takes priority and S. regalis becomes a synonym.
\end{abstract}

Citation: Nitare J, Ainsworth AM, Larsson E, Parfitt D, Suz LM, Svantesson S, Larsson K-H (2021). Four new species of Hydnellum (Thelephorales, Basidiomycota) with a note on Sarcodon illudens. Fungal Systematics and Evolution 7: 233-254. doi: 10.3114/fuse.2021.07.12

Received: 17 November 2020; Accepted: 18 March 2021; Effectively published online: 30 March 2021

Corresponding editor: P.W. Crous

\section{INTRODUCTION}

The stipitate hydnoid fungi within Thelephorales have attracted a lot of interest from environmental and conservation authorities since they are rarely recorded and have shown strong population declines across continental Europe due to atmospheric pollution and unsuitable forestry practices (Hrouda 1999, Nitare 2006, Arnolds 2010, Ozinga et al. 2013, Holec \& Kučera 2018, Nitare 2019). Global conservation assessments have been published for seven species, of which five are currently regarded as Vulnerable (IUCN 2020). Effective conservation measures require a precise knowledge about species diversity and species limits (Runnel et al. 2014). Fungi are often notoriously difficult to identify and morphological differences are often small and based on ambiguous or overlapping character states. The potential presence of cryptic species adds another layer of uncertainty to the evaluation of species ecology, occurrences, geographical distribution, and population trends. Stipitate hydnoid fungi are not exempt from these challenges (Ainsworth et al. 2010, Baird et al. 2013, Loizides et al. 2016).

The genera of the stipitate hydnoid Thelephorales have traditionally been distinguished using two characters, viz. basidiomatal texture and spore colour: dry corky basidiomata in Hydnellum and Phellodon and fleshy basidiomata in Bankera and Sarcodon; brownish spores in Hydnellum and Sarcodon and hyaline spores in Bankera and Phellodon. Information from DNA sequences has shown that this simple and practical classification cannot be maintained. A new classification instead relegates Bankera to the synonymy of Phellodon (Baird et al. 2013), while Sarcodon is much reduced and most of its species have been moved to Hydnellum (Larsson et al. 2019).

Maas Geesteranus successively introduced a subgeneric classification for Sarcodon with six sections (summarised in Maas Geesteranus 1975a). In this classification, most of the 
species treated herein would belong either to section Scabrosi or to section Violacei. Both sections received moderate support, within the genus Hydnellum, in the phylogenetic analyses performed in Larsson et al. (2019).

Typifying section Scabrosi, Hydnellum scabrosum is based on Hydnum scabrosum, a species originally described by Fries from pine forests in Femsjö, SW Sweden (Fries 1836) and later neotypified with a collection from the same area (Maas Geesteranus \& Nannfeldt 1969). Although this species continued to be regarded as a species of coniferous or, occasionally, mixed woodlands in North America (Harrison 1961, Harrison \& Grund 1987), this was not the case in Europe. Maas Geesteranus $(1956,1975 a)$ treated the species in a wider sense and accepted specimens from both broadleaved and conifer forests, a taxonomic view which has prevailed in Europe ever since (e.g. Phillips 1981, Breitenbach \& Kränzlin 1986, Gulden \& Hanssen 1992, Stalpers 1993, Pegler et al. 1997, Hrouda 1999, Arnolds 2003, 2010). However, preliminary analysis of the available molecular data suggested that specimens from broadleaved (e.g. in Brock et al. 2009) and coniferous (e.g. in Nitare \& Högberg 2012) woodlands are genetically different. The British population of the former group was provisionally recognized as "Sarcodon sp. 1 (with Fagaceae)" and unofficially assessed as nationally Endangered (Smith et al. 2016). Intense collecting in Sweden and the UK and subsequent sequencing of material from both forest types was therefore carried out to investigate whether the formal recognition of two distinct species was warranted. While specimens with a Hydnellum scabrosum aspect collected in European broadleaved forests have been interpreted as the true $H$. scabrosum, specimens from coniferous forests have often been identified as other species within section Scabrosi, most commonly as H. glaucopus (Pegler et al. 1997, van der Linde et al. 2008).

In Sweden, the need for conservation measures for Sarcodon species was evaluated and an action plan developed (Nitare 2006). A rare species associated with Pinus was in that report erroneously identified as S. glaucopus. Intensified sampling due to the increased interest that followed from the publication of the report yielded many new collections, some of which could not be included in current species concepts. A provisional description of three potentially new Sarcodon species was published in Nitare \& Högberg (2012), supported by a preliminary analysis of ITS1 sequences. The specimens previously misidentified as S. glaucopus were there reclassified as an undescribed species under the provisional name "S. pseudoglaucopus".

Here we formally describe three new species with a place in section Scabrosi, and one new species belonging to section Violacei. Our phylogenetic analyses further include sequences from the holo-, iso- or neotypes of Hydnellum glaucopus, $\mathrm{H}$. lepidum, H. scabrosum, Sarcodon illudens, and S. regalis. Our aim is to provide an improved taxonomic framework for this group of stipitate hydnoids which will, in turn, lead to the generation of more accurate and reliable distribution and ecological data.

\section{MATERIALS AND METHODS}

\section{Sampling}

The specimens studied were collected in Denmark, Italy, the Netherlands, Norway, Spain, Sweden and the UK over the last two decades, either by ourselves or by colleagues sending material to us. Interesting specimens were also found in the fungaria in Göteborg (GB), Kew (K), Oslo (O), Stockholm (S) and Uppsala (UPS). Studied specimens are listed for each of the species described in the taxonomy section. DNA from a selection of specimens was extracted and sequenced. Our phylogenetic analyses also incorporated sequences downloaded from GenBank and UNITE (Nilsson et al. 2018). Specimens sequenced for this study and their GenBank accession numbers are listed in Table 1.

\section{Microscopy}

Specimens were mounted in $2 \% \mathrm{KOH}$, Melzer's reagent or cotton blue in lactic acid and studied with a Zeiss Axioskop or an Olympus $\mathrm{BH} 2$ light microscope using bright field or phase contrast optics. Spore measurements were made without ornamentation and ornament height was recorded separately. Spore measurements are given as a range covering $90 \%$ of measured spores with $5 \%$ extreme values given within parentheses. The number of collections used $(x)$ and spores measured $(y)$ is provided in the form $n=x / y$. Spores were photographed in a Zeiss Axioskop microscope equipped with a $\times 100$ DIC objective lens, a Zeiss MRc camera, and Zen Blue software. Photographed tissue was mounted in Melzer's reagent.

\section{Molecular methods}

Sequences for the complete ITS region and about 1200 base pairs (bp) of the $5^{\prime}$ end of the LSU (28S) of the nuclear ribosomal DNA were generated using the primers ITS1F (Gardes \& Bruns 1993) and LR21, LROR, and LR7 (Hopple \& Vilgalys 1999). Genomic DNA was extracted from the specimens using the DNeasy Plant Mini Kit (Qiagen, Hilden) and PCR reactions were performed with illustra PuReTaq Ready-To-Go PCR beads (Cytiva, Marlborough) using $0.5 \mu \mathrm{M}$ of each primer and $1-3 \mu \mathrm{L}$ of the DNA extracts. PCR clean-up was carried out using the QIAquick PCR purification kit (Qiagen, Hilden). Sequences were generated by Macrogen Europe (Amsterdam, the Netherlands) using primers ITS1, ITS4 (White et al. 1990), Ctb6 (https://nature.berkeley. edu/brunslab/) and LR5 and LR3R (Hopple \& Vilgalys 1999). Genomic DNA was extracted from old type specimens using a modified CTAB method (Larsson \& Jacobsson 2004) and the ITS1 and ITS2 regions were amplified separately using primers ITS1FITS2 and ITS3-ITS4B respectively (White et al. 1990, Gardes \& Bruns 1993). PCR reactions and clean up followed the methods described above. Primers used for sequencing were ITS1, ITS2, ITS3 and ITS4 (White et al. 1990).

Selected specimens preserved in $\mathrm{K}$ (vouchers prefixed $\mathrm{K}(\mathrm{M})$ in Table 1) were either processed according to the methods outlined in Parfitt et al. (2007) or using the following protocols. Genomic DNA was extracted using an enzymatic digestion and glass-fibre filtration method and the full ITS region amplified with ITS1F and ITS4 primers following Dentinger et al. (2010). DNA from the ectomycorrhizal root tip ALM363 was extracted using Extract-N-Amp (Sigma-Aldrich) and the full ITS region amplified using ITS1F and ITS4 following Suz et al. (2014). PCR products were purified with Exo-SAP-IT (USB) and sequenced bidirectionally using BigDye Terminator v. 3.1 Cycle Sequencing reagents in an ABI 3730 DNA Analyzer (Applied Biosystems). 
Table 1. Specimen data and GenBank numbers for sequences published in this study.

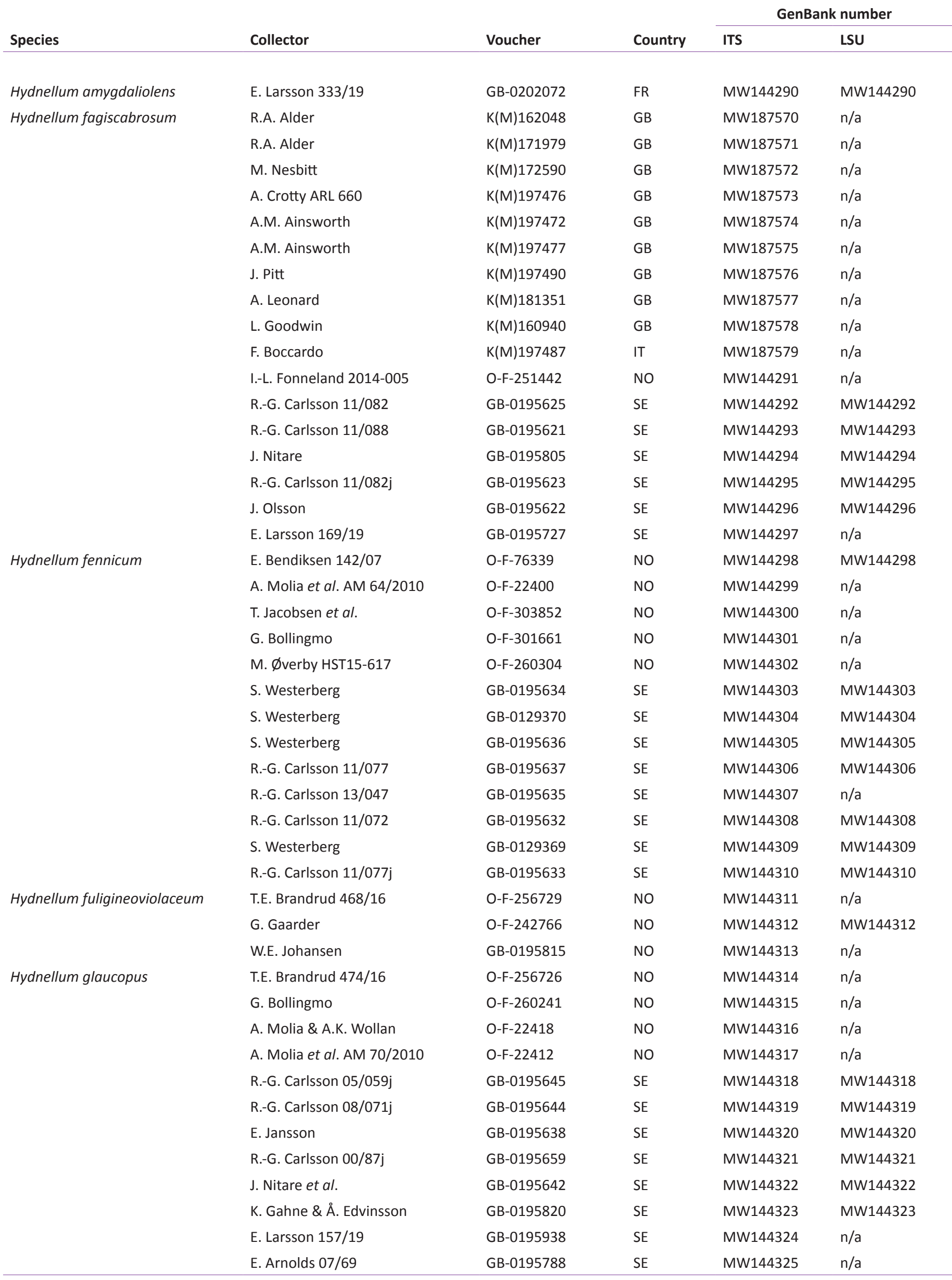


Table 1. (Continued).

Hydnellum illudens

Hydnellum ioeides

Hydnellum lepidum

\begin{tabular}{|c|c|c|c|c|c|}
\hline \multirow[b]{2}{*}{ Species } & \multirow[b]{2}{*}{ Collector } & \multirow[b]{2}{*}{ Voucher } & \multirow[b]{2}{*}{ Country } & \multicolumn{2}{|c|}{ GenBank number } \\
\hline & & & & ITS & LSU \\
\hline & E. Larsson $261 / 11$ & GB-0195722 & SE & MW144326 & MW144326 \\
\hline & R.-G. Carlsson 11/069j & GB-0195639 & SE & MW144328 & MW144328 \\
\hline & L. \& S. Stridvall 11/015 & GB-0195648 & SE & MW144329 & $\mathrm{n} / \mathrm{a}$ \\
\hline \multirow{16}{*}{ Hydnellum illudens } & U. Roffler \& B. Senn-Irlet BSI & & & & \\
\hline & 07/115 & ZT-Myс-64129 & $\mathrm{CH}$ & MW187580 & $\mathrm{n} / \mathrm{a}$ \\
\hline & J. Boiffard & L.09111973 & $\mathrm{FR}$ & MW144331 & $\mathrm{n} / \mathrm{a}$ \\
\hline & E. Arnolds 07/23 & GB-0195786 & IT & MW144332 & $n / a$ \\
\hline & G. Gaarder 6393 & O-F-242769 & NO & MW144335 & MW144335 \\
\hline & T.E. Brandrud 469/16 & O-F-256727 & NO & MW144336 & $n / a$ \\
\hline & T.E. Brandrud 451b/16 & O-F-256728 & NO & MW144337 & $\mathrm{n} / \mathrm{a}$ \\
\hline & S. Svantesson 890 & GB-0195937 & NO & MW144338 & MW144338 \\
\hline & E. Larsson 91/10 & GB-0195721 & SE & MW144339 & MW144339 \\
\hline & E. Larsson 332BA/18 & GB-0195723 & SE & MW144340 & $\mathrm{n} / \mathrm{a}$ \\
\hline & J. Nitare & GB-0195819 & SE & MW144341 & MW144341 \\
\hline & L. Andersson \& T. Fasth & GB-0195651 & SE & MW144342 & MW144342 \\
\hline & L. Andersson \& T. Fasth & GB-0195808 & SE & MW144343 & MW144343 \\
\hline & J. Nitare & GB-0195649 & SE & MW144350 & MW144350 \\
\hline & L. Andersson \& T. Fasth & GB-0195655 & SE & MW144351 & MW144351 \\
\hline & G. Aronsson & GB-0195650 & SE & MW144352 & MW144352 \\
\hline \multirow[t]{10}{*}{ Hydnellum ioeides } & A.M. Ainsworth & K(M)196064 & GB & MW191881 & $\mathrm{n} / \mathrm{a}$ \\
\hline & A.M. Ainsworth & K(M)196065 & GB & MW191882 & $\mathrm{n} / \mathrm{a}$ \\
\hline & D. Mills & $\mathrm{K}(\mathrm{M}) 236333$ & GB & MW187582 & $\mathrm{n} / \mathrm{a}$ \\
\hline & F. Boccardo & K(M)197486 & IT & MW187583 & n/a \\
\hline & R. Kristiansen & O-F-295820 & NO & MW144353 & MW144353 \\
\hline & A. \& B. Nilsson & GB-0129376 & SE & MW144354 & MW144354 \\
\hline & R.-G. Carlsson 11/059j & GB-0195657 & SE & MW144355 & MW144355 \\
\hline & F. Papmehl-Dufay 006 & GB-0195656 & SE & MW144356 & MW144356 \\
\hline & B. \& K. Hjortstam & GB-0195660 & SE & MW144357 & MW144357 \\
\hline & R.-G. Carlsson 11/090j & GB-0195658 & SE & MW144358 & MW144358 \\
\hline \multirow[t]{4}{*}{ Hydnellum lepidum } & T. Borgen DMS-680077 & GB-0207597 & DK & MW144359 & $\mathrm{n} / \mathrm{a}$ \\
\hline & M. Strandberg DMS-9213941 & GB-0207598 & DK & MW144360 & $\mathrm{n} / \mathrm{a}$ \\
\hline & M. Strandberg DMS-168848 & GB-0207599 & DK & MW144361 & $\mathrm{n} / \mathrm{a}$ \\
\hline & D.A. Reid et al. & $\mathrm{K}(\mathrm{M}) 38542$ & GB & MW187584 & n/a \\
\hline
\end{tabular}


Table 1. (Continued).

Hydnellum nemorosum

Hydnellum roseoviolaceum

Hydnellum scabrosellum

Hydnellum scabrosum

\begin{tabular}{|c|c|c|c|c|c|}
\hline \multirow[b]{2}{*}{ Species } & \multirow[b]{2}{*}{ Collector } & \multirow[b]{2}{*}{ Voucher } & \multirow[b]{2}{*}{ Country } & \multicolumn{2}{|c|}{ GenBank number } \\
\hline & & & & ITS & LSU \\
\hline & S. Skeates & K(M)197484 & IT & MW187587 & $\mathrm{n} / \mathrm{a}$ \\
\hline & A. van der Berg EA 00/119 & GB-0195784 & $\mathrm{NL}$ & MW144363 & $\mathrm{n} / \mathrm{a}$ \\
\hline & G. \& H. Piepenbroek & L.0053426 & $\mathrm{NL}$ & MW144364 & $n / a$ \\
\hline & E. Larsson $374 / 17$ & GB-0202073 & SE & MW144366 & $n / a$ \\
\hline & R.-G. Carlsson 07/120 & GB-0195670 & SE & MW144367 & MW144367 \\
\hline & F. Papmehl-Dufay 1401 & GB-0195669 & SE & MW144368 & MW144368 \\
\hline & E. Larsson 358/16 & GB-0195739 & SE & MW144369 & $\mathrm{n} / \mathrm{a}$ \\
\hline \multirow{4}{*}{ Hydnellum nemorosum } & A.M. Ainsworth & K(M)197478 & GB & MW187588 & $\mathrm{n} / \mathrm{a}$ \\
\hline & A.M. Ainsworth & K(M)197481 & GB & MW187589 & $\mathrm{n} / \mathrm{a}$ \\
\hline & I.-L. Fonneland 11/191 & O-F-242352 & NO & MW144372 & MW144372 \\
\hline & D. Broström 00/114 & GB-0195631 & SE & MW144373 & MW144373 \\
\hline \multirow[t]{2}{*}{ Hydnellum roseoviolaceum } & B. Petterson & GB-0195936 & SE & MW144374 & MW144374 \\
\hline & D. Broström 08/033 & GB-0195687 & SE & MW144375 & MW144375 \\
\hline \multirow[t]{3}{*}{ Hydnellum scabrosellum } & E. Larsson 317/16 & GB-0195736 & SE & MW144376 & $\mathrm{n} / \mathrm{a}$ \\
\hline & J. Nitare & GB-0195806 & SE & MW144377 & MW144377 \\
\hline & G. Aronsson 130920 & GB-0195791 & SE & MW144378 & MW144378 \\
\hline \multirow{17}{*}{ Hydnellum scabrosum } & R.-G. Carlsson 99/071j & GB-0195696 & SE & MW144385 & MW144385 \\
\hline & E. Larsson 220/11 & GB-0195731 & SE & MW144386 & $\mathrm{n} / \mathrm{a}$ \\
\hline & J.-O. Tedebrand & GB-0195691 & SE & MW144387 & MW144387 \\
\hline & R.-G. Carlsson 13/068 & GB-0195694 & SE & MW144388 & MW144388 \\
\hline & E. Larsson 332B/18 & GB-0195726 & SE & MW144389 & $\mathrm{n} / \mathrm{a}$ \\
\hline & V. Fägersten & GB-0195692 & SE & MW144390 & MW144390 \\
\hline & A. Pallin & GB-0195794 & SE & MW144391 & $\mathrm{n} / \mathrm{a}$ \\
\hline & R.-G. Carlsson 08/145j & GB-0195699 & SE & MW144392 & MW144392 \\
\hline & R.-G. Carlsson 11/095j & GB-0195701 & SE & MW144393 & MW144393 \\
\hline & R.-G. Carlsson 10/046 & GB-0195698 & SE & MW144394 & MW144394 \\
\hline & R.-G. Carlsson 11/095 & GB-0195700 & SE & MW144395 & MW144395 \\
\hline & L. Ljungberg & GB-0195690 & SE & MW144396 & MW144396 \\
\hline & R.-G. Carlsson & GB-0195697 & SE & MW144397 & MW144397 \\
\hline & A. Stridvall et al. & GB-0195693 & SE & MW144398 & $n / a$ \\
\hline & E. Larsson $268 / 18$ & GB-0195730 & SE & MW144399 & $\mathrm{n} / \mathrm{a}$ \\
\hline & S. Lundell & UPS F-013954 & SE & MW144400 & $\mathrm{n} / \mathrm{a}$ \\
\hline & T.E. Brandrud 536/13 & O-F-249353 & NO & MW144401 & MW144401 \\
\hline
\end{tabular}




\section{Phylogenetic analyses}

Three datasets were compiled and manually aligned in AliView v. 1.26 (Larsson 2014). In the first dataset we used 5.8S and ca. $900 \mathrm{bp}$ from the $5^{\prime}$ end of $28 \mathrm{~S}$ from the nuclear ribosomal repeat. We based this alignment on Larsson et al. (2019) but restricted the dataset to Hydnellum and added Sarcodon leucopus as outgroup. We further added sequences from the five species that are the focus of this study together with sequences of $H$. fuscoindicum that, in Larsson et al. (2019), was recovered as a sister taxon to $H$. fuligineoviolaceum. The second and third datasets consisted of ITS sequences for the species in section Scabrosi and section Violacei, respectively, following the analyses in Baird et al. (2013) and Larsson et al. (2019). Hydnellum aurantiacum was selected as the outgroup for the Scabrosi dataset and $H$. peckii was the corresponding selection made for the Violacei dataset. We augmented our ITS datasets for each of our focus species with available sequences downloaded from the GenBank and UNITE databases.

Maximum Likelihood (ML) analyses were conducted with IQ-TREE (Nguyen et al. 2015) using the online server at http:// iqtree.cibiv.univie.ac.at/ (Trifinopoulos et al. 2016). ITS1, 5.8S, ITS2 and 28S were treated as separate partitions (Chernomor et al. 2016). The best-fitting substitution model was estimated using ModelFinder implemented on the IQ-TREE server (Kalyaanamoorthy et al. 2017). Branch support was estimated through the SH-aLRT test (Guindon et al. 2010) and through ultrafast bootstrap (Hoang et al. 2018), both of which are available on the IQ-TREE server.

Bayesian Inference (BI) was calculated using MrBayes v. 3.2 (Ronquist et al. 2012) implemented on the CIPRES Science Gateway server v. 3.3 (Miller et al. 2010) and utilizing the BEAGLE library (Ayres et al. 2012). The same partitions as in the $\mathrm{ML}$ analyses were used. Substitution models were selected with MrModeltest v. 2 (Nylander 2004). Analyses of the Hydnellum and the Violacei dataset were run for $5 \mathrm{M}$ generations, sampling trees every $1000^{\text {th }}$ generation. The Scabrosi dataset was run for $8 \mathrm{M}$ generations with the same sampling frequency. Other program settings were the default ones.

\section{RESULTS}

For the present study 136 Hydnellum specimens and one ectomycorrhizal root tip were sequenced. This resulted in 137 full or partial ITS sequences and 67 LSU sequences, all of which are deposited in GenBank (Table 1).

All $\mathrm{BI}$ analyses reached stationarity long before termination and chain-mixing was satisfactory. For the Hydnellum analysis, a burn-in of $25 \%$ was used but for the other two analyses a $50 \%$ burn-in was necessary to ensure that only trees with average standard deviation of split frequencies below 0.01 were included when computing the consensus trees.

The trees are labelled with support values and only strong branch support is shown. The first number represents the $\mathrm{SH}$ aLRT test from the ML runs and values from $80 \%$ are indicated. The second number is the outcome of the ultrafast bootstrap from $\mathrm{ML}$ analyses and values from $95 \%$ are shown. The third figure is the posterior probability from the $\mathrm{BI}$ analyses and here values from 0.95 are shown.

After alignment the Hydnellum dataset included 1553 positions. Nine of these positions could not be reliably aligned and were discarded prior to analyses. $\mathrm{ML}$ and $\mathrm{BI}$ analyses of the
Hydnellum dataset showed largely similar topology and the ML tree is presented here (Fig. 1). Sections Violacei and Scabrosi are recovered as strongly supported. In addition, $H$. aurantiacum and $H$. auratile form a supported clade. The relationships among these three clades and the rest of the species are not resolved. Twenty-five terminal clades with strong support from at least two branch support tests represent an equal number of species. In addition, the single sequence of $H$. amygdaliolens is recovered on a separate branch. Of the terminal clades four could not be connected to existing species names and are here interpreted as the new species Hydnellum fagiscabrosum, $\mathrm{H}$. nemorosum, $H$. roseoviolaceum, and $H$. scabrosellum (see Taxonomy section below). The taxon provisionally called "Sarcodon pseudoglaucopus" can now be identified as S. illudens (Maas Geesteranus 1976) following our phylogenetic analyses which included a sequence derived from the holotype of that species. The new combination Hydnellum illudens is proposed.

European specimens of each species generally showed no or little genetic variation within the ITS region. On the other hand, the genetic infraspecific variation was often considerable, which caused difficulties for the alignment. We still decided not to discard any ambiguous nucleotide positions since our aim with the ITS trees was not primarily to evaluate the phylogenetic relationships among species but to visualize the amount of genetic difference between species and the extent of morphological identifications within species.

After alignment the Violacei dataset included 673 nucleotide positions. $\mathrm{ML}$ and $\mathrm{BI}$ analyses of the Violacei dataset are identical and the $\mathrm{ML}$ tree is presented here (Fig. 2). All terminal clades are supported by at least two branch support tests. Seven terminal clades represent four known species, one new species described here as Hydnellum roseoviolaceum, and two unidentified North American taxa, one of them represented only by environmental DNA.

After alignment the Scabrosi dataset included 694 nucleotide positions. $\mathrm{ML}$ and $\mathrm{BI}$ analyses of section Scabrosi are not fully congruent with respect to the placement of Hydnellum scabrosum. In the ML analysis $H$. scabrosum occupies a separate branch while in the $\mathrm{BI}$ analysis $H$. scabrosum is paraphyletic in relation to $H$. fennicus, $H$. amygdaliolens, $H$. nemorosum and an unidentified species. The ML tree is shown in Fig. 3. Nine terminal clades are supported by at least two branch support tests while the clade formed by $H$. scabrosum sequences, including that derived from the neotype, is visible in the tree but not supported. Supported clades correspond to six known species and three new species, here described as Hydnellum fagiscabrosum, $H$. nemorosum, and $H$. scabrosellum.

\section{Taxonomy}

Hydnellum fagiscabrosum A.M. Ainsw. \& Nitare, sp. nov. MycoBank MB 837984. Figs 4A, C-F, 9A.

Etymology: Epithet derived from fagi-, referring to the association with Fagales (e.g. Castanea, Fagus and Quercus) and scabrosum, referring to the morphological similarity to Hydnum scabrosum Fr.

Typus: Sweden, Blekinge, Ronneby, north-eastern shore of lake Listersjön, close to a picnic area, near Fagus sylvatica, 56.320946/15.350357, 3 Sep. 2014, J. Nitare (holotypus GB0195805; isotypi K(M)264450, UPS); GenBank accession: MW144294. 


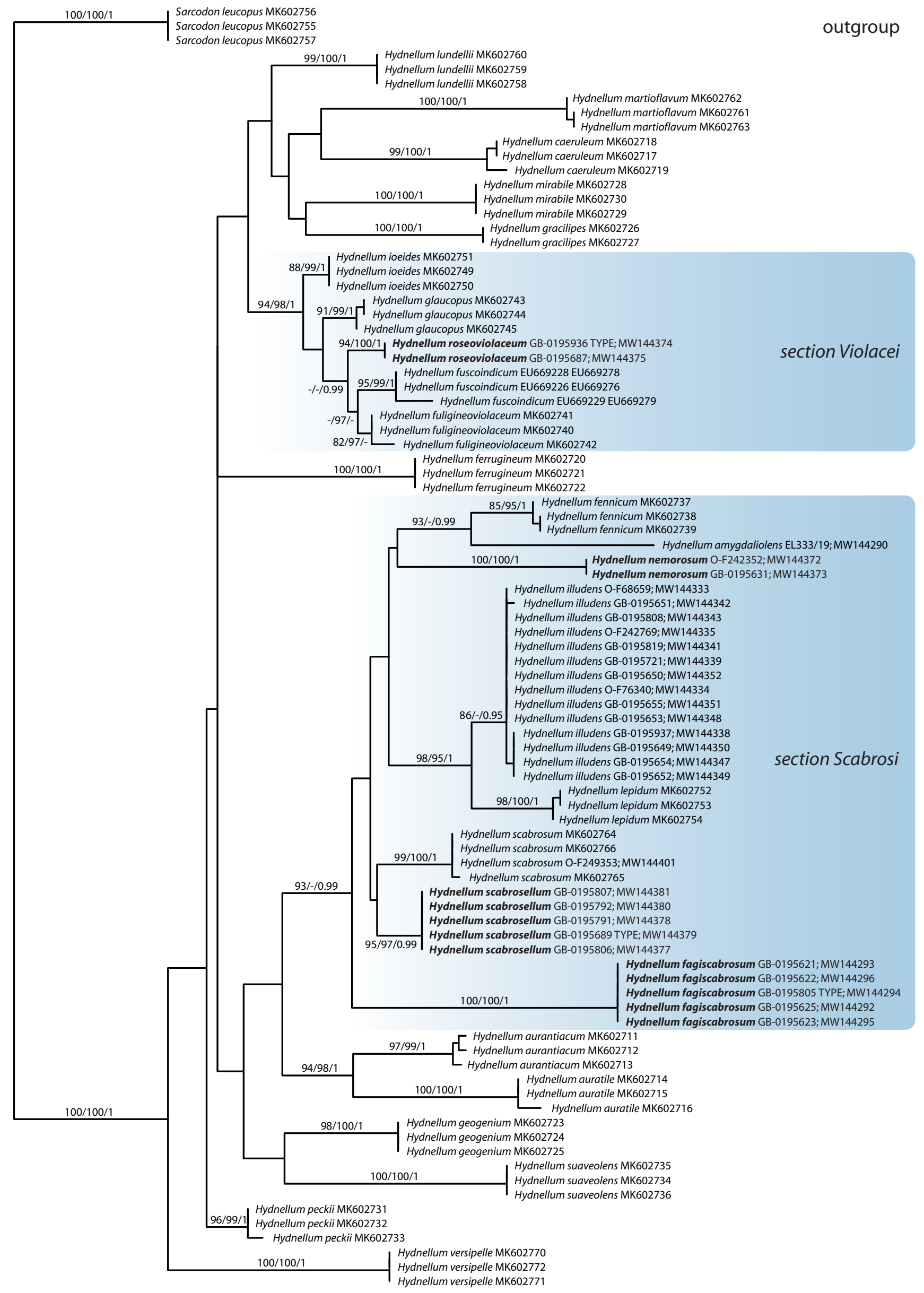

Fig. 1. Phylogram of Hydnellum. Maximum Likelihood tree based on nuclear ribosomal $5.8 \mathrm{~S}$ and partial $28 \mathrm{~S}$ sequences. Numbers on branches represent reliable support values from SH-aLRT test ( $\geq 80 \%$ ), ultrafast bootstrap ( $\geq 95 \%$ ), and Bayesian inference posterior probability values ( $\geq$ $0.95)$, respectively. Species described here are marked in bold face. 


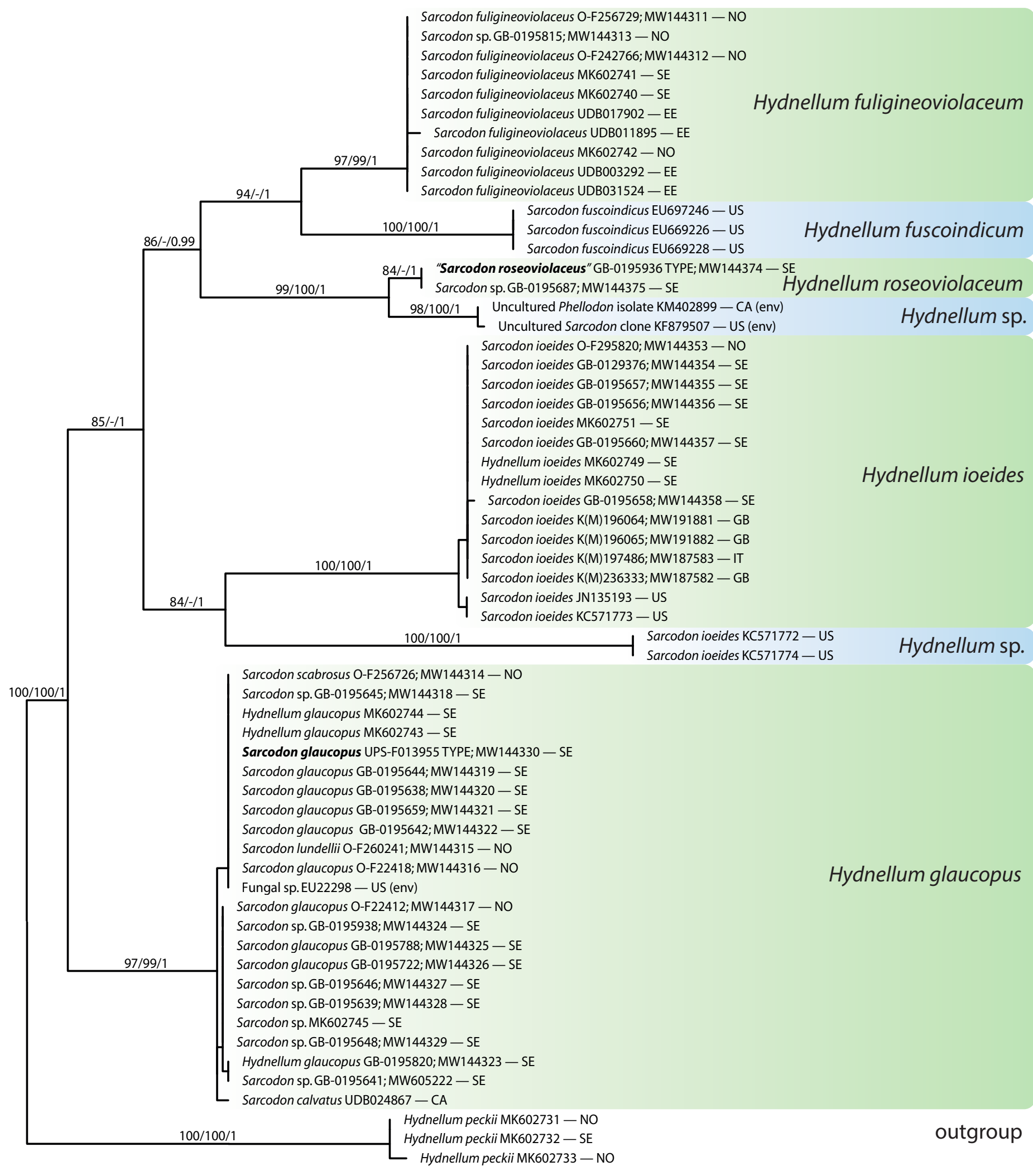

Fig. 2. Phylogram of Hydnellum section Violacei. Maximum Likelihood tree based on nuclear ribosomal ITS sequences. Numbers on branches represent reliable support values from SH-aLRT test $(\geq 80 \%$ ), ultrafast bootstrap ( $\geq 95 \%$ ), and Bayesian inference posterior probability values ( $\geq$ $0.95)$, respectively. Terminal names are the original identification. Sequences from type specimens are marked in bold face. Sequences not generated from basidiomata are marked as env(ironmental).

Misapplication: Sarcodon scabrosus (at least in part) sensu European authors.

Selected illustrations (all labelled as S. scabrosus): Breitenbach \& Kränzlin [1986: 235 (no. 279)], Maas Geesteranus (1975a: taf. 34 abb. a), Pegler et al. (1997: fig. 77 showing micromorphology of specimen K(M)30165 sequenced by Brock et al. 2009).

Description: Basidiomata terrestrial, stipitate, medium to rather large and fleshy, solitary or clustered, often in small groups. 
Pileus 50-140 mm broad, irregularly rounded to lobate, initially convex, umbonate or plane, usually developing a depressed centre at maturity; margin thin, undulating and initially incurved; cuticle radially fibrillose, showing superficial tearing to produce marginal areolae and zones of concentric scales, sometimes terminating in an upturned pointed darker tip, and deeper tearing to produce radial fissures in the underlying paler context and a central zone of coarse block-like scales; initially pinkish red brown, sometimes showing lilac or pale violaceous tints, with whitish growing edge, becoming progressively darker towards the centre and entirely chestnut brown or black brown with age. Stipe 30-100 × 10-30 mm, cylindrical or basally tapered with smooth, scaly, longitudinally fibrillose texture or covered by rudimentary or entire spines; concolourous with the pileus at the apex and distinctly bluish-green to black at the base with whitish mycelium binding the soil. Spines not, slightly or strongly decurrent, up to $10 \times 1 \mathrm{~mm}$, light greyish brown with whitish tips at first, becoming progressively browner from the base. Flesh not zoned, whitish, with distinctive greyish- or bluish-green patch within the base of the stipe, smell farinaceous, taste farinaceous and bitter. Chemical reaction: when a drop of $3 \% \mathrm{KOH}$ is added to dry specimens, the pileipellis becomes darker brown and the flesh becomes pale brown. Hyphal system monomitic, all hyphae simple septate, tramal hyphae of spines up to $8 \mu \mathrm{m}$ wide. Basidia clavate, with four sterigmata. Basidiospores brown, subglobose or short ellipsoid, irregularly tuberculate, with oblique apiculus, $4.5-6.3(-6.4) \times(3.5-) 3.8-5.3(-5.6) \mu \mathrm{m}, \mathrm{av} .=5.4 \times 4.7 \mu \mathrm{m}, \mathrm{Q}$ $=0.9-1.5(n=4 / 100$, measurements from the lateral side without tubercles), tubercles numerous, up to $1.3 \mu \mathrm{m}$ high, with rounded, flat-topped or exsculpate apices.

Ecology and distribution: We conclude that this species is ectomycorrhizal from the placement of GenBank sequence MF946050 which was obtained from an American ectomycorrhizal root tip of Quercus section Lobatae and identified as S. scabrosus in Rasmussen et al. (2018). From field observations we infer that $H$. fagiscabrosum is a mycorrhizal partner of Fagus sylvatica, Quercus spp. and Castanea sativa, including coppiced non-native Castanea in the UK. It is mostly found in the nemoral vegetation zone in sandy or gravelly soils, usually with other stipitate hydnoids, and often on mossy embankments, tracksides, ditchsides or in similarly nutrient poor microhabitats. The true extent of its European distribution is currently unknown due to its former inclusion within the circumscription of S. scabrosus, but we have produced molecular evidence for its presence in Norway, Sweden, UK and Italy and therefore suspect it is a very widespread, albeit relatively uncommon, member of the European Fagaceae-associated stipitate hydnoid community. Placement of GenBank sequences in Fig. 3 demonstrate that $\mathrm{H}$. fagiscabrosum is also present in the southeastern USA in Florida, North Carolina and Tennessee where it has been assigned to S. scabrosus (Hughes et al. 2009, Baird et al. 2013, Rasmussen et al. 2018).

Additional specimens examined: Italy, Liguria, Savona, Sassello, Badami, on soil near Castanea sativa, 2 Sep. 2010, F. Boccardo K(M)197487 (as S. regalis). Norway, Agder, Tvedestrand, $N$ of $\varnothing$ ynesvann, trackside in Quercus forest, 23 Aug. 2014, I.-L. Fonneland \& D. Pettersen O-F-251442. Sweden, Bohuslän, Lysekil par., Vägeröds dalar, on soil with Quercus sp. and Tilia cordata, E. Larsson GB-0195727; Sotenäs and Tossene par., Hogsäm, on soil under Fagus sylvatica, R.-G. Carlsson GB-0195621, GB-0195625; Tanum par., Lindö, on soil with Quercus sp., Tilia cordata, and Corylus avellana, J. Olsson GB-0195622; Västergötland, Sätila par., Ramhultafallet, on soil with Quercus sp. and Corylus avellana, R.-G. Carlsson GB-0195621. UK, Berkshire (VC22), Windsor Crown Estate, on soil near Castanea sativa, 28 Sep. 1979, R. Phillips K(M)119189 (as S. scabrosus); Windsor Crown Estate, Buttersteep area (dry ditch), (SU9065), on soil near Castanea sativa, 2 Sep. 2005, A.M. Ainsworth K(M)197477 (as S. scabrosus); Windsor Crown Estate, Buttersteep Hill, (SU9066), on soil near Castanea sativa, 29 Sep. 2008, A.M. Ainsworth K(M)197472 (as Sarcodon sp.); East Norfolk (VC27), St Faith's Common (TG181173), on soil near Castanea sativa, 22 Sep. 2011, A. Crotty K(M)197476 (as S. scabrosus); South Hampshire (VC11), New Forest, Brock Hill area (SU27020553), on soil near Quercus sp. and Fagus sylvatica, 9 Oct. 2011, M. Nesbitt K(M)172590 (as S. scabrosus); New Forest, Roydon Woods (SU313000), on soil, 11 Sep. 2002, A. Leonard K(M)181351 (as S. scabrosus); New Forest, Vinney Ridge (SU26290518), on soil near Quercus sp., 17 Sep. 2010, A. Lucas Hyd229 (as S. scabrosus); Surrey (VC17), Witley Common (SU92553982), on soil near Quercus sp. and Castanea sativa, 13 Sep. 2008, L. Goodwin K(M)160940 (as S. scabrosus); Woking (TQ018605), on soil near Quercus sp., Castanea sativa and Pinus sylvestris, 31 Jul. 2007, R.A. Alder K(M)162048 (as S. scabrosus); ibid., 6 Sep. 2011, R.A. Alder K(M)171979 (as S. scabrosus); West Kent (VC16), Seal Chart (TQ567557), on soil near Quercus petraea, 11 Oct. 2010, J. Pitt K(M)197490; Tudeley Woods, on soil near Castanea sativa, 24 Sep. 1994, N. Fletcher K(M)30165, (as S. scabrosus); ibid., 15 Oct. 1999, J. Weightman K(M)64653 (as S. scabrosus).

Notes: Historically, our species has been included in a broad concept of Sarcodon scabrosus which has an inferred association with both Fagaceae and Pinaceae, at least in Europe. However, based on its protologue, the discussion in Maas Geesteranus \& Nannfeldt (1969) and the clustering of a sequence derived from its neotype with several sequences derived from coniferassociated basidiomata and mycorrhizal root samples (see Fig. 3), Hydnellum scabrosum sensu stricto was revealed to be an ectomycorrhizal partner of Pinaceae only. More specifically, it was detected in the roots of Pinus sylvestris in Estonia (UNITE UDB008050), of Pinus densiflora (GenBank AB251833) in Japan (Lian et al. 2006) and of Pseudotsuga menziesii (GenBank KM402896) in Canada (Kranabetter et al. 2015). Furthermore, European basidiomatal sequence and collection data indicate that it is usually found on poor sandy soils with $P$. sylvestris and never in pure stands of Fagaceae. It should also be noted in passing that the placement of GenBank sequence AF351870 in Fig. 3 indicates that, in Oregon at least, H. scabrosum sensu stricto can also form mycorrhizal associations with epiparasitic monotropoid plant roots (Bidartondo \& Bruns 2001).

Hitherto, H. fagiscabrosum was recognized as "Sarcodon sp. 1 (with Fagaceae)" in the UK (Smith et al. 2016) and as "H. fagiscabrosum nom. prov." in Sweden (Nitare 2019). We have not been able to find any usable existing name for this misinterpreted species, and old names such as Hydnum amarescens Quél., a fairly pale and minutely scaly species with a non-existent type fide Maas Geesteranus (1956), are all dubious and have been applied to other species (see e.g. discussion in Maas Geesteranus \& Nannfeldt 1969). Therefore, we prefer to give this widely distributed species a new name.

The basidiomata of $H$. fagiscabrosum, $H$. illudens and $H$. scabrosum are similarly coarsely scaly when fully mature, but these species differ in their pileal pigmentation and ecological associations. In the field, $H$. fagiscabrosum can be distinguished from $H$. scabrosum by the relatively persistent, often broad and contrastingly whitish pileal margin of the former and its 
Sarcodon scabrosus GB-0195729; MW144383 - SE

Sarcodon glaucopus EU622394 - GB

Uncultured Sarcodon KM402896 - CA (env)

Sarcodon glaucopus EU622385 - GB

Sarcodon cf glaucopus MF954692 - CA

Sarcodon cf. glaucopus GB-0195695; MW144384 - SE

Sarcodon scabrosus GB-0195696; MW144385 - SE

Sarcodon scabrosus MK602766 - NO

Sarcodon glaucopus EU622389 - GB

Sarcodon scabrosus GB-0195731; MW144386 - SE

Sarcodon glaucopus EU622395 - GB

Sarcodon scabrosus GB-0195691; MW144387 - SE

Sarcodon glaucopus EU622391 - GB

Sarcodon glaucopus EU622390 - GB

Sarcodon scabrosus GB-0195694; MW144388 - SE

Sarcodon scabrosus GB-0195726; MW144389 - SE

Sarcodon scabrosus GB-0195692; MW144390 - SE

Sarcodon scabrosus GB-0195794; MW144391 - SE

Sarcodon glaucopus JO888205 - GB

Sarcodon scabrosus GB-0195699; MW144392 - SE

Sarcodon glaucopus UDB018559- EE

Sarcodon scabrosus GB-0195701; MW144393 - SE

Sarcodon scabrosus GB-0195698; MW144394 — SE

Sarcodon glaucopus EU622387 - GB

Sarcodon scabrosus GB-0195690; MW144396 - SE

Sarcodon scabrosus GB-0195700; MW144395 - SE

Sarcodon scabrosus GB-0195697; MW144397 — SE

Sarcodon scabrosus GB-0195702; MW144382 - FI

Sarcodon glaucopus UDB015701 - EE

Sarcodon glaucopus EU784402 - GB

Sarcodon glaucopus EU622393 - GB

Sarcodon glaucopus EU622384 - SE

Sarcodon glaucopus UDB015662 - EE

Sarcodon glaucopus UDB011450 - EE

Bankeraceae UDB008050 - EE (env)

Sarcodon glaucopus UDB018047 - EE

Sarcodon sp. AF351870 - US (env)

Sarcodon cf. glaucopus MK602764 - NO

Sarcodon scabrosus GB-0195693; MW144398 - SE

"Sarcodon pseudoglaucopus" GB-0195730:MW144399 - SE

Sarcodon glaucopus O-F249353; MW144401 - NO

Sarcodon glaucopus EU622392 - GB

Sarcodon glaucopus MK602765 - NO

Sarcodon scabrosus K(M)25139; MW202245 - GB

Sarcodon glaucopus EU622386 - GB

Sarcodon glaucopus EU622388 - GB

Sarcodon glaucopus UDB003279 - EE

Sarcodon scabrosus UPS-F013954 TYPE; MW144400 - SE

Fungal sp. EU222972 - US (env)

Uncultured fungus KF617227 - US (env)

Sarcodon cf. glaucopus MF954691 - CA

Sarcodon sp. AB251833 - JP (env)

Sarcodon scabrosus LC373251 - JP

Sarcodon fennicus MK602737 - NO

Sarcodon fennicus EU627606 - SE

Sarcodon fennicus GB-0195634; MW144303 - SE

Sarcodon fennicus O-F76339; MW144298 - NO

Sarcodon fennicus GB-0129370; MW144304 — SE

Sarcodon fennicus EU627605 - SE

Sarcodon scabrosus MK602739 - SE

Sarcodon fennicus O-F22400;MW144299 - NO

Sarcodon fennicus GB-0195636; MW144305 — SE

Sarcodon fennicus MK474928 - AT

Sarcodon fennicus MK474928 - AT
Sarcodon fennicus MK474929 - AT

Sarcodon fennicus O-F303852; MW144300 - NO

Sarcodon fennicus GB-0195637; MW144306 - SE

Sarcodon fennicus GB-0195635; MW144307 - SE

Sarcodon fennicus GB-0195632; MW144308 - SE

Sarcodon fennicus O-F301661; MW144301 - NO

Sarcodon fenicus O-F301661; MWV 144301 - NO

Sarcodon fennicus O-F260304; MW144302 - NO

Sarcodon glaucopus MK602738 - NO

Sarcodon fennicus GB-0195633; MW144310 - SE 00/100/1

Hydnellum scabrosum

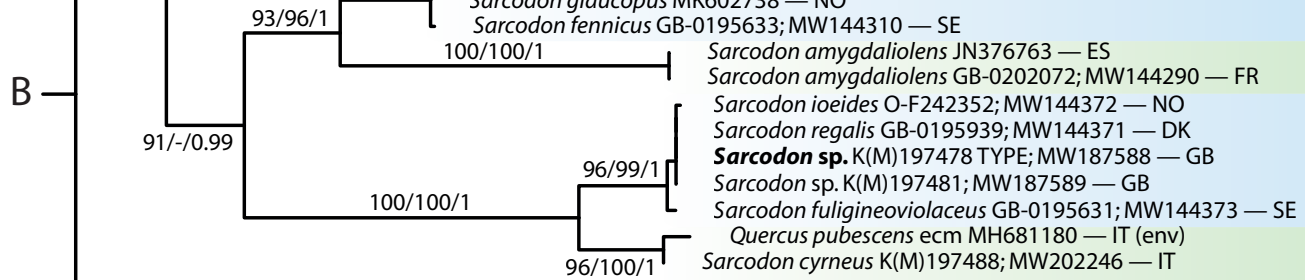

Hydnellum amygdaliolens

Hydnellum nemorosum

Sarcodon cyrneus?

Hydnellum cf.fennicus GB-0195736; MW144376 - SE arcodon cyrneus K(M)197488; MW202246 - IT

Hydnellum fennicum

"Sarcodon scabrosellus"GB-0195806;MW144377 - SE

"Sarcodon scabrosellus" GB-0195791;MW144378 - SE

"Sarcodon scabrosellus" GB-0195689 TYPE; MW144379 — SE

82/-/0.99 "Sarcodon scabrosellus" GB-0195792; MW144380 — SE

Hydnellum scabrosellum

Fig. 3. Phylogram of Hydnellum section Scabrosi. Maximum Likelihood tree based on nuclear ribosomal ITS sequences. Numbers on branches represent reliable support values from SH-aLRT test ( $\geq 80 \%$ ), ultrafast bootstrap ( $\geq 95 \%$ ), and Bayesian inference posterior probability values ( $\geq$ 0.95), respectively. Terminal names are the original identification. Sequences from type specimens are marked in bold face. Sequences not generated from basidiomata are marked as env(ironmental). 


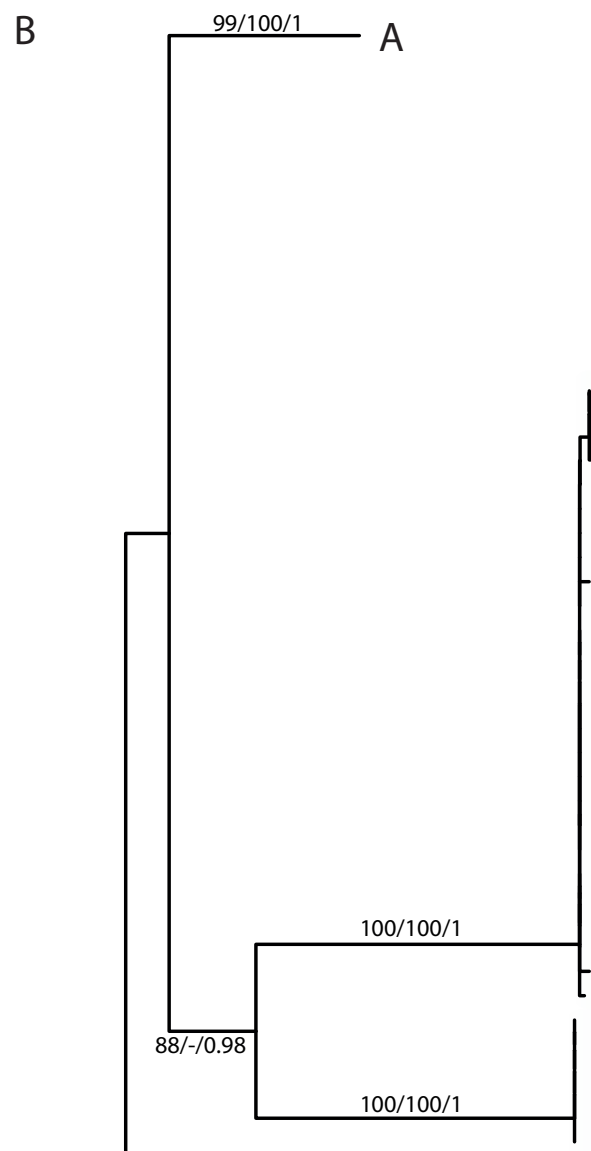

Sarcodon scabrosus K(M)162048; MW187570 - GB Sarcodon scabrosus K(M)171979; MW187571 — GB

Sarcodon scabrosus K(M)172590; MW187572 - GB Sarcodon scabrosus K(M)197476; MW187573 - GB Sarcodon regalis K(M)197487; MW187579 - IT

Sarcodon scabrosus K(M) 197472; MW187574-GB

Sarcodon scabrosus K(M)197477; MW187575-GB

Sarcodon scabrosus K(M)197477; MW187575 - GB

Sarcodon scabrosus K(M) 197490;MW187576 - GB

Sarcodon sp. FJ596768 - US

Sarcodon lepidus GB-0195625; MW144292 - SE

Sarcodon scabrosus GB-0195621; MW144293 - SE

Sarcodon scabrosus K(M)181351; MW187577 - GB

Sarcodon cf. regalis GB-0195805 TYPE; MW144294 - SE

Sarcodon scabrosus KC571775 - US

Sarcodon scabrosus K(M) 160940; MW187578 - GB

Sarcodon scabrosus O-F251442; MW144291 - NO

Sarcodon lepidus GB-0195623; MW144295 - SE

Sarcodon sp. GB-0195622; MW144296 - SE

Hydnellum sp. GB-0195727; MW144297 - SE

Sarcodon scabrosus EU784404 - GB

Sarcodon scabrosus EU784404 - GB

Sarcodon scabrosus EU784403 - GB
Sarcodon scabrosus KC571776 - US

Sarcodon scabrosus KC571778 - US

Sarcodon scabrosus JN135192 - US

Sarcodon scabrosus KC571777 — US

Uncultured fungus MF946050 — US (env)

Sarcodon underwoodii JN135189 - US

Sarcodon underwoodii KC571780 - US

Sarcodon underwoodii MH910597 - US

Sarcodon underwoodii KC571781 — US

Sarcodon underwoodii KC571779 - US

Sarcodon cf. glaucopus O-F68659; MW144333 - NO

Sarcodon glaucopus GB-0195721; MW144339 - SE

Sarcodon versipellis O-F76340; MW144334 - NO

Hydnellum illudens GB-0195723; MW144340 - SE

"Sarcodon pseudoglaucopus" GB-0195819; MW144341 - SE

Sarcodon sp. GB-0195937; MW144338 - NO

Sarcodon cf. scabrosus O-F242769; MW144335 - NO

Sarcodon fennicus/glaucopus GB-0195651; MW144342 - SE

Sarcodon fennicus GB-0195808; MW144343 - SE

Hydnellum illudens GB-0195724; MW144344 - SE

"Sarcodon pseudoglaucopus"O-F256727:MW144336 - NO

"Sarcodon scabrosellus" GB-0195802; MW144345 - SE

Sarcodon scabrosus UDB019706 - EE

Sarcodon scabrosus UDB003282 - EE

Sarcodon scabrosus UDB003274 - EE

Sarcodon glaucopus/scabrosus GB-0195787; MW144346 - SE

Sarcodon cf. lepidus GB-0195786; MW144332 - IT

"Sarcodon pseudoglaucopus"O-F256728; MW144337 - NO

Sarcodon regalis ZT-Myc-64129; MW187580-CH

Sarcodon sp. GB-0195654;MW144347 - SE

Sarcodon cf. fennicus GB-0195653; MW144348 - SE

Sarcodon cyrneus K(M)197492; MW187581 - IT

Sarcodon scabrosus UDB017878 - EE

Sarcodon sp. GB-0195652; MW144349 - SE

Sarcodon illudens L.09111973 TYPE; MW144331 - FR

Sarcodon sp. GB-0195655; MW144351 - SE

Sarcodon pseudoglaucopus" GB-0195

Sarcodon scabrosus DBO

Sarcodon imbricatus UDB024054 - CA

Sarcodon regalis $\mathrm{K}(\mathrm{M}) 38542 \mathrm{TYPE} ; \mathrm{MW} 187584$ - GB

Ecm root tip ALM363 - ES (env)

Sarcodon scabrosus K(M) 197484; MW187587 — IT

Sarcodon scabrosus K(M) 197482; MW187585 — IT

Sarcodon scabrosus K(M) 197483; MW187586 - IT

Sarcodon lepidus MK602754 - SE

Bankera violascens O-F302063; MW144365 - NO

Hydnellum sp. GB-0207599; MW144361 - DK

Hydnellum sp. GB-0207599; MW144361 - DK
Sarcodon cf. leucopus GB-0202073; MW144366 - SE

Sarcodon lepidus MK602752 - SE

Sarcodon lepidus GB-0195670; MW144367 - SE

Sarcodon lepidus GB-0195669; MW144368 - SE

Sarcodon lepidus MK602753 - SE

Sarcodon cf. lepidus GB-0195739; MW144369 - SE

Sarcodon lepidus GB-0195785: MW144362 - NL

"Sarcodon pseudoglaucopus" GB 0195804: MW144370 - SE

Sarcodon underwoodii GB-0195784; MW144363 - NL

Sarcodon sp. JN135195 - US

$100 / 100 / 1$

Hydnellum sp. GB-0207597; MW144359 - DK

Sarcodon sp. GB-0207598; MW144360 - DK

Sarcodon lepidus L.0053426 TYPE; MW144364 - NL

Fig. 3. (Continued). 

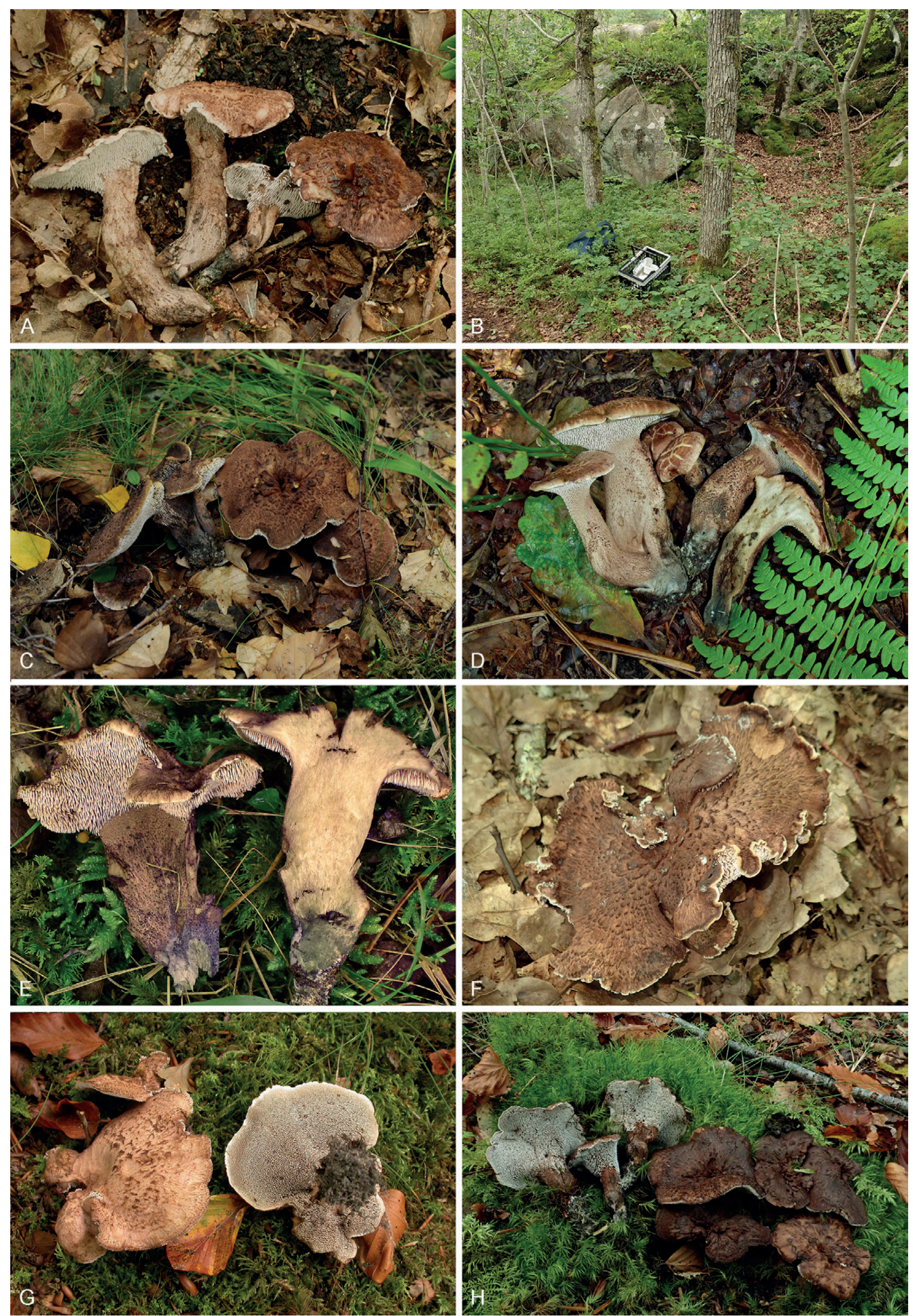

Fig. 4. A. Hydnellum fagiscabrosum GB-0195727. B. Collecting site for GB-0195727. C. H. fagiscabrosum holotype, GB-0195805. D. H. fagiscabrosum O-F-251442, photo I.-L. Fonneland. E. H. fagiscabrosum Hyd229, photo A. Lucas F. H. fagiscabrosum GB-0195622, photo J. Olsson. G. Hydnellum lepidum DMS-680077, photo T. Borgen. H. H. lepidum GB-0202073. 
association with Fagaceae. Hydnellum scabrosum has a more concolorous pileal margin and it associates with Pinaceae. Although $H$. illudens and $H$. fagiscabrosum might be found in similar habitats in southern Europe, they differ in basidiomatal colours. The pileal surface is yellowish brown in $H$. illudens and the dried flesh also assumes a yellowish colour, whereas the pileus is reddish brown in $H$. fagiscabrosum and the flesh remains greyish when dried. Furthermore, basidiomata of $H$. illudens have a strongly farinaceous taste, whereas those of $H$. fagiscabrosum are rather sour and acrid.

Hydnellum fagiscabrosum is distinguished from $\mathrm{H}$. nemorosum and $H$. lepidum, both of which are associated with broadleaved trees, by its more coarsely scaly pileus. Of these species, $H$. nemorosum differs the most with its pinkish to vinaceous-brown pileus which is fissured but not really scaly, whereas in $\mathrm{H}$. lepidum the scales are small and more or less adpressed all over the pileal surface.

Hydnellum illudens (Maas Geest.) Nitare, comb. nov. MycoBank MB 837988. Figs 5A-D, 9C.

Basionym: Sarcodon illudens Maas Geest., Proc. K. Ned. Akad. Wet., Section C 79(3): 285. 1976.

Synonym: "Sarcodon pseudoglaucopus", Nitare nom. prov. in Nitare \& Högberg (2012).

Misapplication: Sarcodon glaucopus sensu Nitare, 2006, non Maas Geesteranus \& Nannfeldt, 1969.

Selected illustrations (as "Sarcodon pseudoglaucopus" Nitare nom. prov.): Nitare \& Högberg (2012: fig. 9A-F).

Typus: France, Vendée, Saint-Hilaire-de-Talmont, "Le Veillon", under an old Quercus ilex, 4 Nov. 1973, J. Boiffard L.09111973 (holotype).

Description: Basidiomata terrestrial, stipitate, fleshy and compact, single or concrescent. Pileus $70-120 \mathrm{~mm}$, convex to plano-convex, centrally somewhat depressed, ochraceous to fulvous brown, sometimes darker in the middle. Cuticle initially slightly tomentose, dry, first loosely covered by a thin cottony tomentum-layer of ephemeral whitish to pale rose hyphae (mostly whitish, but sometimes with slightly pinkish tints, often seen only in the expanding margin), with age becoming smooth, more or less glabrescent, from the centre more or less cracked into areoles and small adnate scales. Stipe 40-60 × 15-30 mm, above concolourous with the pileus, tapering downwards with a short rooting point, at the base white-tomentose or greyish blue to olivaceous grey (usually only at the rooting point, but sometimes developing a blue-grey base of the stipe). Spines strongly decurrent, but rarely reaching the middle of the stipe, up to $5 \mathrm{~mm}$ long, crowded, at first pallid, then becoming yellowish brown, when dried yellowish to ochraceous. Flesh not zoned, when fresh pale greyish, when dry (exsiccates) yellowish to ochraceous. Smell subfarinaceous, taste at first strongly farinaceous, mild or slightly acid or bitterish, after a short while leaving a more intensely bitter taste with farinaceous components. Chemical reaction. When adding $3 \% \mathrm{KOH}$ on dry specimens, only the pileipellis (not the flesh) immediately changes colour to charcoal black. Hyphal system monomitic, all hyphae simple septate, spine trama hyphae up to $7 \mu \mathrm{m}$ wide. Basidia clavate, with four sterigmata. Basidiospores pale brownish, globose or irregularly subglobose, tuberculate, with oblique apiculus, 4.7-5.7(-6.1) × 3.5-4.5 $\mu \mathrm{m}, \overline{\mathrm{x}}=5.2 \times 4.0 \mu \mathrm{m}, \mathrm{Q}$ $=1.2-1.5(n=3 / 90$, measurements from the lateral side without tubercles), tubercles numerous, $0.4-0.9 \mu \mathrm{m}$ high, with rounded, flat-topped or exsculpate apices.

Ecology and distribution: Associated with Picea, Pinus or Quercus on calcareous or somewhat base-rich soils, often in sandy and dry places. In addition to the type locality in France it is known from calcareous ground in several districts in Sweden within the hemiboreal, southern boreal and middle boreal vegetation zones. It is confirmed also from southern to central Norway, Estonia, Switzerland, and Italy. A sequence (UDB024054) deposited in the UNITE database under the name Sarcodon imbricatus proved to be this species. The sequence was generated from a basidioma collected in conifer forest in NW British Columbia, Canada, making it the first report of Hydnellum illudens from North America.

Additional specimens examined: Italy, Puglia, Bari, Casamasella 14 km E of Maglia, old forest of Quercus ilex on calcareous soil, 6 Jan. 2007, E. Arnolds GB-0195786; Sardinia, Baldo, near Quercus suber, Cistus, Arbutus, 12 Nov. 2006, C.A. Hobart K(M)197492 (as S. cyrneus). Norway, Nord-Trøndelag, Steinkjer, Kalvøya, on soil with Pinus sylvestris, H. Holien, O-F-68659; Hedmark, Hamar, Furuberget nat. res., K. \& E. Bendiksen O-F-76340; Viken, Ringerike, SW of Ultvedt, on soil in conifer forest, G. Gaarder O-F-242769; Ultveitvatnet nat. res., on soil in conifer forest, 25 Sep. 2010, S. Svantesson GB-0195937; Ultvedtåsen, calcareous Pinus forest, 16 Sep. 2016, T.E. Brandrud \& B. Dima O-F256728; Nordbyåsen, calcareous Pinus forest with some Picea, 20 Sep. 2016, T.E. Brandrud \& B. Dima O-F-256727. Sweden, Dalarna, Rättvik, Rättviksheden, "Gropen", sandy Pinus heath, 5 Sep. 2004, J. Nitare GB-0195825 (fig. 9E \& F in Nitare \& Högberg 2012; ITS1 JX999975); Kalkverket SO, lichen-rich Pinus forest, 21 Aug. 2010, E. Larsson GB0195721; Enån nat. res., Kungshol, sandy Pinus heath, 7 Sep. 2018, E. Larsson GB-0195723, GB-0195724; Gotland, Gothem, Åminne, Tjälders, on soil in mixed conifer forest on limestone, 23 Aug. 2005, J. Nitare GB-0195803 (ITS: 1 JX999984); 26 Sep. 2011, J. Nitare GB-0195649; Gästrikland, Gävle, Limön, Oxharen, mixed conifer forest, 18 Aug. 2012, L. Andersson \& T. Fasth GB-0195651; NE of the café, Picea forest with some Pinus on diabase, 18 Aug. 2012 L. Andersson \& T. Fasth GB0195808; Limön 18 Aug. 2012, L. Andersson \& T. Fasth GB 0195652, GB0195653, GB-0195654, GB-0195655; Uppland, Älvkarleby, Billudden, Brämsand, on soil in calcareous sandy Pinus sylvestris forest, $12 \mathrm{Sep}$. 2007, J. Nitare GB-0195818 (fig. 9A in Nitare \& Högberg 2012; ITS: 1 JX999985); 10 Oct. 2010, G. Aronsson GB-0195650 10; 14 Sep. 2009, J. Nitare GB-0195819 (fig. 9B \& 9C in Nitare \& Högberg 2012); Västland, Östervret, calcareous Picea forest, 16 Sep. 2016, J. Nitare GB-0195802; Öland, Böda, Böda kronopark, Pinus forest on windblown coastal sand-dunes, 8 Oct. 2007, E. Arnolds GB-0195787.

Notes: This species differs macroscopically from Hydnellum scabrosum, $H$. fagiscabrosum and $H$. glaucopus by its ochraceous to fulvous brown cuticle (almond-brown or like café-au-lait) without copper-rufous (reddish) or violaceous colours and in dried exsiccates by its yellowish-ochraceous flesh and hymenium (spines). Both $H$. illudens and $H$. scabrosum can associate with Pinus, but $H$. illudens is found on base-rich soils whereas $H$. scabrosum is found mostly on acidic soils. Hydnellum illudens usually produces smaller and more compact and sturdier basidiomata compared to H. scabrosum. Hydnellum glaucopus can also be distinguished from the others by its smaller basidiospores which are 4-4.5 $\mu \mathrm{m}$, evenly subglobose 

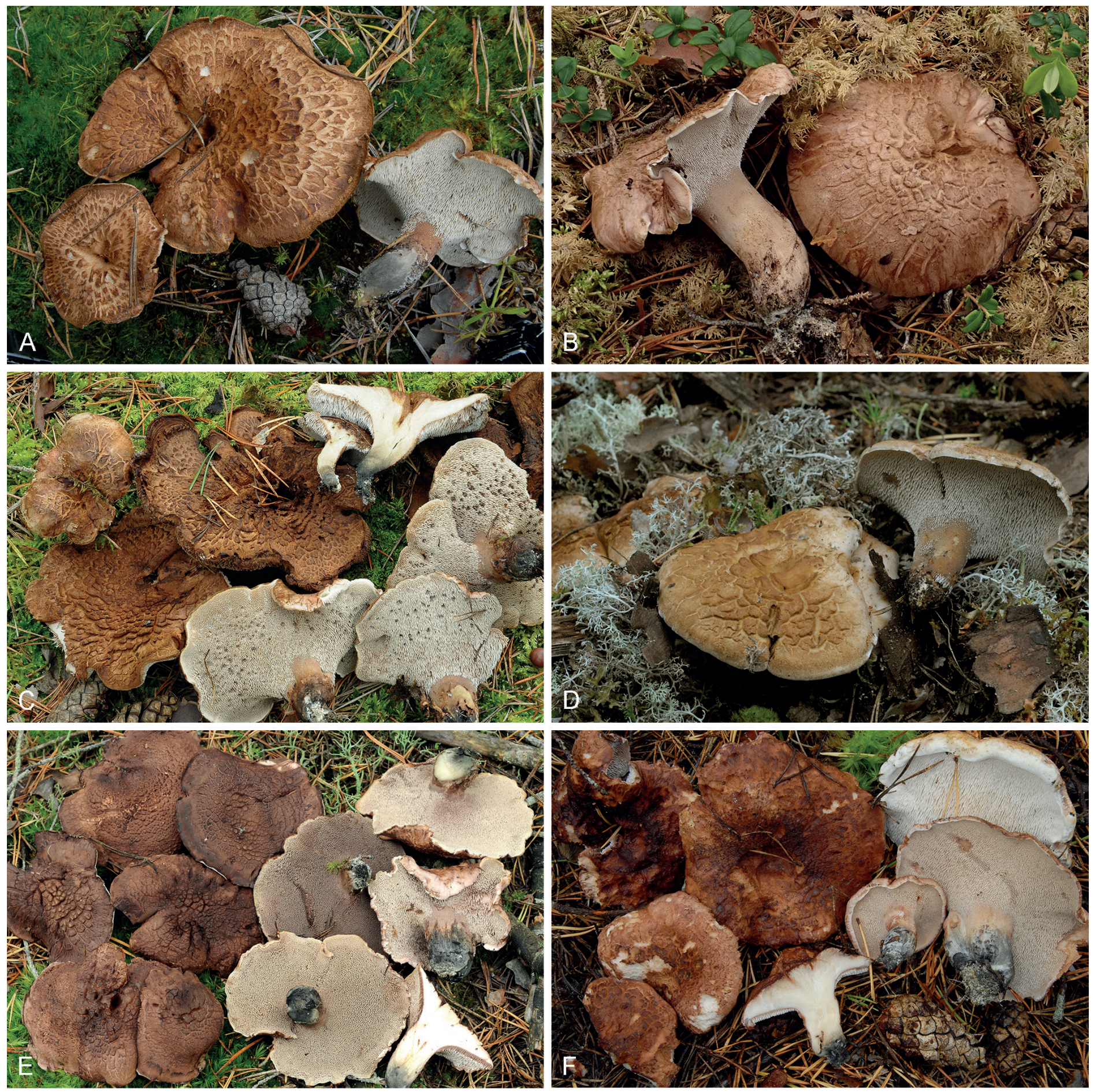

Fig. 5. A. Hydnellum illudens TU106275 (UDB003274), photo V. Liiv. B. H. illudens GB-0195724. C. H. illudens TU106475 (UDB015699), photo V. Liiv. D. H. illudens GB-0195818. E. Hydnellum scabrosum TU106993 (UDB015662), photo V. Liiv. F. H. scabrosum TU106280 (UDB003279), photo V. Liiv.

and ornamented with rather slender evenly spread spines that are rarely twinned. By contrast, the larger basidiospores (up to $6.5 \mu \mathrm{m}$ long) of $H$. fagiscabrosum, $H$. illudens and $H$. fagiscabrosum are slightly irregular and ornamented with rather coarse, frequently twinned (exsculpate) spines.

Maas Geesteranus (1976) regarded H. lepidum (as Sarcodon) as the most closely related species. This observation is confirmed by the molecular phylogeny where the two species cluster together with high support.

Since its description from a single specimen the species has been little reported and seemingly ignored or misunderstood by European mycologists. The specimens we have sequenced were either not fully identified or assigned to Sarcodon cyrneus, $S$. fennicus, S. glaucopus, S. regalis, S. scabrosus, S. versipellis or to the provisional name "S. pseudoglaucopus".

Two sequenced Italian specimens (GB-0195786, K(M)197492) were collected under Quercus ilex and $Q$. suber, respectively, which is also the normal habitat for Sarcodon cyrneus. The possibility that $H$. illudens can associate with Quercus trees implies that ecology alone may not suffice to separate $H$. illudens from $H$. lepidum. See also notes to $H$. nemorosum below.

Hydnellum nemorosum A.M. Ainsw. \& E. Larss. sp. nov. MycoBank MB 837985. Figs 6A, C, D, 9E. 

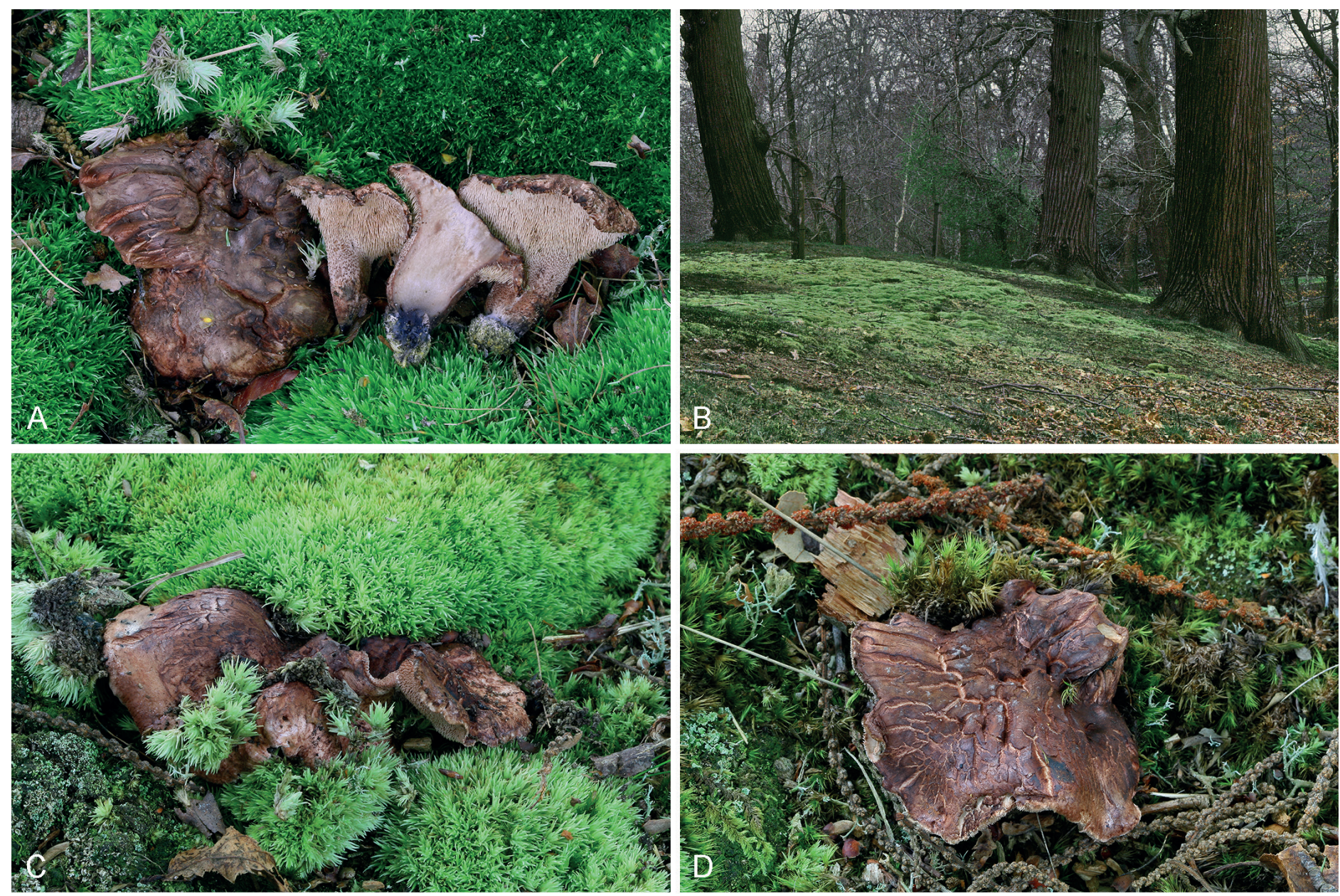

Fig. 6. A. Hydnellum nemorosum K(M)197481. B. H. nemorosum type locality. C, D. H. nemorosum holotype, K(M)197478.

Etymology: The epithet nemorosum refers to broadleaved trees which are thought to be the mycorrhizal partners of this species. Typus: UK, Berkshire (VC22), Windsor Great Park, Johnson's Pond (SU96676951), on a moss-covered (Leucobryum) sandy mound near Castanea sativa, with Pinus sylvestris and Quercus robur further away, 51.416389/-0.611111, 15 Sep. 2008, A.M. Ainsworth (holotypus K(M)197478; isotypus GB-0207601); GenBank accession: MW187588.

Description: Basidiomata terrestrial, stipitate, medium-sized and fleshy, solitary or clustered, often in small groups. Pileus 40-100 mm broad, irregularly rounded to lobate, initially convex or umbonate, becoming more plane with age and sometimes developing a depressed centre; margin thin, undulating and remaining long incurved; cuticle initially almost smooth, matt, becoming pellicular and sometimes shiny in places, occasionally showing superficial tearing to produce a few marginal areolae and zones of poorly-developed appressed scales, and more frequently becoming deeply lacerated to produce radial fissures in the underlying paler context and a central zone of coarse block-like scales; initially pinkish or vinaceous brown, with whitish growing edge, becoming progressively darker reddish or vinaceous brown towards the centre and blackening with age. Stipe $20-60 \times 10-30 \mathrm{~mm}$, cylindrical or basally tapered with a smooth or fibrillose texture and sometimes covered by rudimentary or entire spines; concolourous with the young pileus at the apex, darker below and distinctly bluish-green to black at the base with whitish mycelium binding the soil. Spines to some degree decurrent, up to $5 \times 1 \mathrm{~mm}$, pinkish brown with whitish tips at first, becoming progressively vinaceous and browner from the base. Flesh not zoned, whitish with pink tinges becoming more vinaceous when exposed to the air by tearing of pileal surface, with distinctive greyish- or bluishgreen patch within the base of the stipe, smell farinaceous but with a penetrating fruity element, taste farinaceous and bitter. Chemical reaction: when a drop of $3 \% \mathrm{KOH}$ is added to dry specimens, the pileipellis becomes darker brown and the flesh becomes pale brown. Hyphal system monomitic, all hyphae simple septate, tramal hyphae of spines up to $6.5 \mu \mathrm{m}$ wide. Basidia clavate, with four sterigmata. Basidiospores brown, subglobose or short ellipsoid, irregularly tuberculate, with oblique apiculus, (3.0-)3.4-5.1(-5.3) × (2.8-)3.0-3.8(-4.5) $\mu \mathrm{m}$, av. $=4.1 \times 3.4 \mu \mathrm{m}, \mathrm{Q}=1.0-1.6(\mathrm{n}=4 / 100$, measurements from the lateral side without tubercles), tubercles numerous, $0.2-0.8$ $\mu \mathrm{m}$ high, with rounded, flat-topped or exsculpate apices.

Ecology and distribution: We are of the opinion that this species is ectomycorrhizal, although we are currently unaware of any ectomycorrhizal root tip DNA evidence to confirm this. From field notes accompanying the specimens sequenced, we conclude that, although records are comparatively sparse, this species is found in mixed or broadleaved woodland and is therefore almost certainly a mycorrhizal partner of various broadleaved tree species. Hosts are likely to include Castanea sativa, Fagus sylvatica and Quercus spp. It should be noted, however, that there were no representatives of Fagaceae recorded near our species in the mixed woodland present at the sampled Swedish locality (see Additional specimens examined). Our choice of 
epithet for this species therefore reflects our greater degree of uncertainty regarding the range of its mycorrhizal partners compared to our state of knowledge regarding $\mathrm{H}$. fagiscabrosum. It has been found in sandy or gravelly soils, sometimes with other stipitate hydnoids, and seemingly with a preference for raised or sloping ground or similarly nutrient poor microhabitats. The true extent of its European distribution is currently unknown due to the current paucity of known collections. It may have been misdetermined as a range of Sarcodon species in the past, but there are so few records to date that it could well be a genuine rarity. Thus far, we have produced molecular evidence for its presence in northern and western Europe (Denmark, Norway, Sweden and the UK), although this is currently restricted to just a single site in each country.

Additional specimens examined: Denmark, Jylland, Silkeborg, Kobskov, on mineral soil on sloping ground near Fagus sylvatica, 15 Sep. 2017, T. Borgen DMS-9211777 (GB-0195939) (as S. regalis). Norway, Aust-Agder, Grimstad, Bakken Nord, on soil in steep southwest facing Quercusdominated broadleaved woodland, 19 Sep. 2011, I.-L. Fonneland O-F242352 (as S. ioeides). Sweden, Dalarna, Rättvik, Rättviksheden, on soil amongst mosses in mixed forest (but no Fagus or Quercus present), 8 Sep. 2000, D. Broström GB-0195631 (as S. fuligineoviolaceus). UK, same details as for holotype, 25 Sep. 2010, A.M. Ainsworth K(M)197481 (as Sarcodon sp.)

Notes: This species has been described and illustrated online under the name Sarcodon regalis sensu Strandberg \& Borgen in Danmarks svampeatlas (Strandberg \& Borgen 2020) wherein it was documented repeatedly at a single Danish location between 2002 and 2019. It has also been recognized as "Sarcodon sp. 2" in an unofficial species conservation assessment (Data Deficient) in the UK (Smith et al. 2016). Two other names (see above) have been misapplied to this species in Norway and Sweden and both are likely to have arisen due to the dominant dark purplish brown pigmentation of its mature basidiomata. We do not know if this species occurs in southern Europe but, if it is present in any historical collections, there is at least one further name that should be included in the search, namely S. cyrneus. This is another broadleaved tree associate which was described from two Corsican collections (Maas Geesteranus 1975a, b). Its protologue refers to its pinkish and purplish brown colours and poorly defined pileal scales, morphological characters which are reminiscent of $H$. nemorosum, but, critically, the two species differ in the pigmentation at the base of the stipe. Indeed, Maas Geesteranus (1975a) keys his species in section Squamiceps rather than section Scabrosi based on its lack of bluish or greenish colours in the stipe base. Furthermore, the illustration of the dried holotype in Maas Geesteranus (1975a) seems too pale to be $H$. nemorosum and there is also a difference in spore length. Bearing in mind that Maas Geesteranus' (1971) spore measurements of Hydnellum and Sarcodon always included the ornamentation, he stated that the length of "probably not mature" spores of S. cyrneus ranges from (5.8-)6.3-7.3 $\mu \mathrm{m}$ whereas the corresponding values obtained for our specimens of $H$. nemorosum $(n=100)$ are $4.5-5.8(-6.0) \mu \mathrm{m}$. It would have been very interesting to include authentic S. cyrneus in our analyses but, unfortunately, our attempts to generate a sequence from type material were unsuccessful (see Discussion for further remarks on $S$. cyrneus).
Hydnellum roseoviolaceum Nitare sp. nov. MycoBank MB 837986. Figs 7A-C, 9F.

Etymology: Epithet derived from roseo $(\mathrm{L})=$ rose, referring to the rosy (rose-coloured) basidiomatal context, combined with violaceum (violet-coloured) referring to its tendency to change colour to violet-lilac.

Typus: Sweden, Härjedalen, Sveg, Fisktjärnområdet, Ytterberg, in dry, lichen-dominated, seminatural old pine heath forest on acidic sand together with Cladonia spp., 62.072398/14.541843, 19 Sep. 2009, B. Petterson \& S. Pratheepchuang (holotypus GB0195936; isotypi O, UPS); GenBank accession: MW144374.

Description. Basidiomata terrestrial, stipitate, fleshy and compact, simple, often rather small and slender. Pileus (30-)50-80 mm broad, convex to plano-convex, somewhat depressed in the centre, with undulating edge, ochraceous brown, tobacco/cigarbrown to reddish brown, with blackish spots in old or damaged parts. Pileus becoming more-or-less dirty black-spotted due to blackening of the hypodermis. Cuticle (pileipellis) dry, epidermis in young basidiomata forming a very thin brown tomentum, later becoming almost smooth, with no radially arranged fibrils, but with short and very small adnate hairy tufts from agglutination of tomentum hyphae (only seen under a lens), in patches sometimes cracked into small areoles. Dry specimens sometimes with small yellowish dots of excreted matter. Stipe 40-60 × (5-)10-15 mm, concolourous with the pileus, tapering downwards and with a short greyish-blue rooting point. Spines strongly decurrent, but rarely reaching the middle of the stipe, up to $5 \mathrm{~mm}$ long, crowded, with age dark brown, but for a long time pallid at the tip. Flesh not zoned, first pinkish to rosy, becoming violaceous to lilac in about $20 \mathrm{~s}$, at least in the central parts of the basidioma, more-or-less blackening when drying. No particular smell, taste mild. Chemical reaction. When adding $3 \% \mathrm{KOH}$ to dry specimens, both the pileipellis and flesh (trama) immediately change colour to charcoal black. Hyphal system monomitic, all hyphae simple septate, tramal hyphae in spines up to $10 \mu \mathrm{m}$ wide. Basidia clavate, clampless, with 4 sterigmata. Basidiospores pale brownish, globose or subglobose, tuberculate, with oblique apiculus, 4.3-5.1 × 3.2-4.2 $\mu \mathrm{m}, \mathrm{av} .=4.7 \times 3.6 \mu \mathrm{m}, \mathrm{Q}=1.1-1.5(\mathrm{n}=2 / 48$, measurements from the lateral side without tubercles), tubercles numerous, $0.5-0.8$ $\mu \mathrm{m}$ high, with prominent rounded apices.

Ecology and distribution: Presumably ectomycorrhizal with Pinus sylvestris. Found in old, seminatural Pinus stands (pine heaths) on dry, acidic sandy soil with Cladonia lichens. Only known from three records (two localities) in eastern central Sweden, within the middle and northern boreal vegetation zones in areas with a rather continental climate.

Additional specimens examined: Sweden, Härjedalen, Sveg, Fisktjärnområdet, Ytterberg, 29 Aug. 2008, P. Hedberg (UPS) (= first record at the type locality); Dalarna, Våmhus, Kumbelnäs, Bonäsheden, old pine heath on fossil eolian sand-dunes, 8 Sep. 2008, D. Broström GB-0195687.

Notes: Among the hydnoid fungi associated with Pinus sylvestris, Hydnellum roseoviolaceum seems to be very close to, and has been mistaken for, $H$. fuligineoviolaceum due to its tendency to assume a lilac flesh. It differs by smaller spores, colour changes in the flesh from rose to violet (not being violet from the beginning 

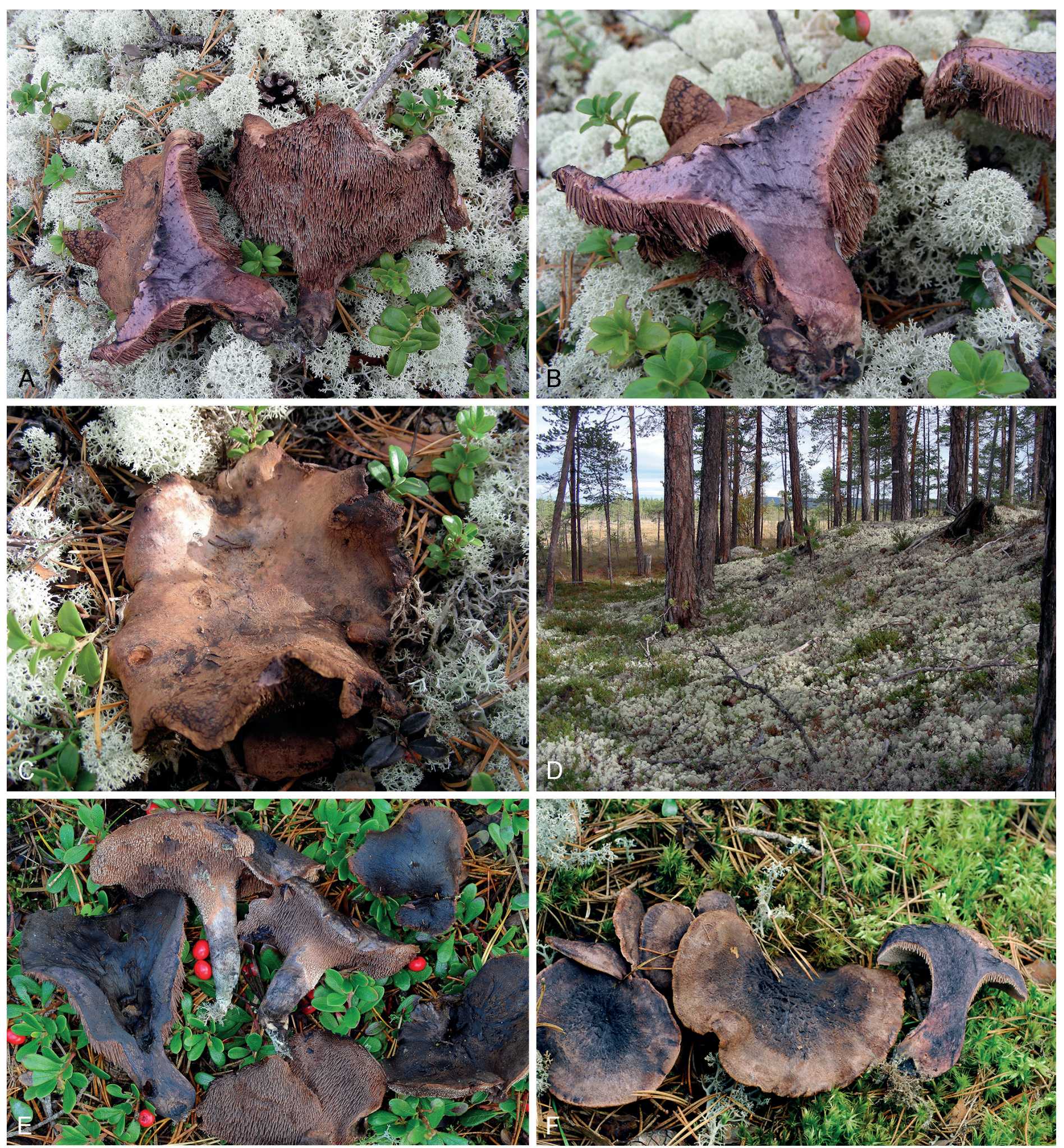

Fig. 7. A-C. Hydnellum roseoviolaceum, holotype, GB-0195936, photos B. Pettersson. D. H. roseoviolaceum type locality, photo B. Pettersson. E. H. fuligineoviolaceum TU106391 (UDB011895), photo V. Liiv. F. H. fuligineoviolaceum GB-0195817.

as in H. fuligineoviolaceum) and its mild taste (N.B. some people cannot detect the very acrid taste of $H$. fuligineoviolaceum). It differs from $H$. glaucopus e.g. by its more intense rose-lilac flesh and by being associated with Pinus (not Picea) on acidic, noncalcareous sites. The pictures, and partly the description, of $S$. fuligineoviolaceus, by Maas Geesteranus (1975a, e.g. plate 38) seem very similar to those of this new species (collections from Greece not checked) and this may be due to a misapplication of the name.
To compare the newly described species with Kalchbrenner and Fries' original concept of Hydnum fuligineo-violaceum, the Carpathian collection from pinewoods at Olaszi (now Spišské Vlachy in Slovakia) made in Sept. 1870 and bearing Fries' handwriting (UPS, F-173546) was studied. The collection is selected as the type by Maas Geesteranus (1975a) but he refrained from a precise designation by writing "(Holo?)Typus". This is probably the original collection Fries refers to as v. s. (= vidi siccam; I have seen it dry) (Fries 1874). The material consists of 

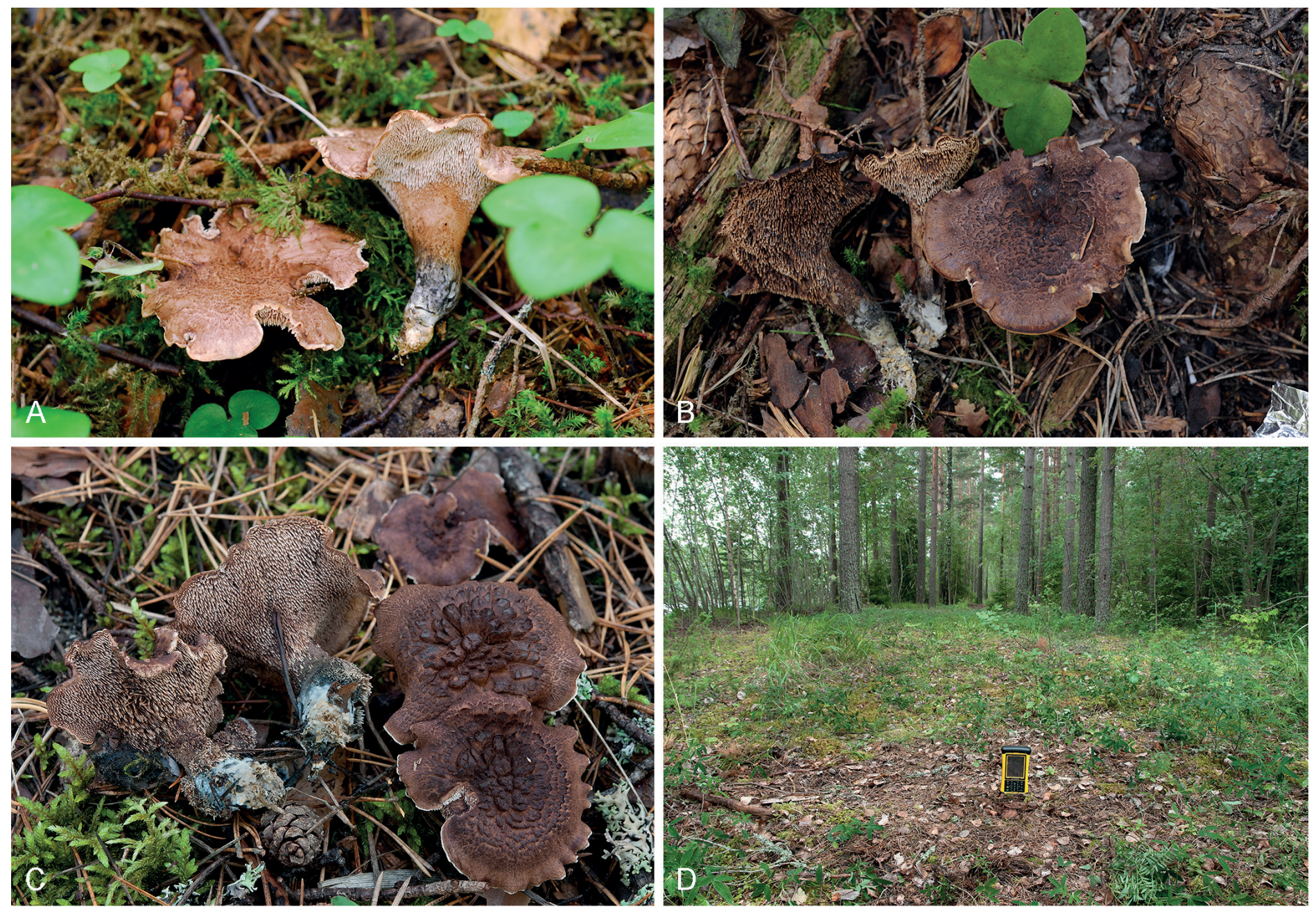

Fig. 8. A. Hydnellum scabrosellum, young basidiomata from the type locality, GB-0195806. B. H. scabrosellum holotype, mature basidiomata, GB0195689. C. H. scabrosellum GB-0195791, photo G. Aronsson. D. H. scabrosellum, collecting site for GB-0195791, photo G. Aronsson.

one small basidioma divided in three slices. The flesh is typically bluish-violet-grey (also in the spines) and the spores are 5.1-6.2 $\times 3.4-4.4 \mu \mathrm{m}$, av. $=5.6 \times 3.7 \mu \mathrm{m}(\mathrm{n}=32$, measurements from the lateral side without tubercles), tubercles $0.6-0.8 \mu \mathrm{m}$ high. Kalchbrenner's collection therefore represents, without doubt, the present concept of Hydnellum fuligineoviolaceum.

An ITS BLAST search in GenBank brings up two western North American sequences as the closest matches at 95-96\%. These sequences are both generated from ectomycorrhizal root-tips, one from a Pinus muricata stand in northern California (Moeller et al. 2014), the other from Pseudotsuga menziesii in British Columbia (Kranabetter et al. 2015). The sequence difference to $H$. roseoviolaceum consists of 15 indels and 14 gaps. We currently cannot suggest any name for this American sister taxon, if any exists. If the basidiomatal colours are like those of $H$. roseoviolaceum, it is likely to become misidentified as $H$. fuscoindicum.

Hydnellum scabrosellum Nitare sp. nov. MycoBank MB 837987. Figs 8A-C, 9G.

Etymology: Epithet derived from scabros[um] and -ellum (L. dim.) referring to "the small scabrosum" (= Hydnum scabrosum Fr.).

Typus: Sweden, Uppland, Börstil parish, Tvärnö, Tuskö, Tuskösundet nat. res. ("Återvändan”), in herb-rich conifer forest dominated by Picea abies with some scattered old Pinus sylvestris, on strongly calcareous moraine on the edge of an old abandoned mine-shaft, 60.22267/18.49009, 13 Sep. 2012, J. Nitare (holotypus GB-0195689; isotypi O, UPS); GenBank accession: MW144379.

Description: Basidiomata terrestrial, stipitate, thin and slender, single or concrescent. Pileus 30-60(-100) mm broad, planoconvex to depressed, with undulating thin margin. Cuticle fibrillose and scaly, cracking up from the centre, at first rosy to pinkish, with whitish growing edge, with age becoming coppery or vinaceous reddish-brown to purplish-brown, with darkening blackish-brown scales in the centre. Stipe 30-60 × 5-10 mm, above ochraceous pinkish-brown or concolourous with the pileus, tapering downwards, at the base bluish-grey or blackishgreen under a white mycelial cover. Spines strongly decurrent, often reaching the middle of the stipe, up to $5 \mathrm{~mm}$ long, crowded, at first pallid and whitish, by age becoming yellowish brown, when dry yellowish to ochraceous. Flesh not zoned, fresh pale, when dry (exsiccates) yellowish-ochraceous brown. Smell subfarinaceous, taste bitterish. Chemical reaction. When adding $3 \% \mathrm{KOH}$ to dry specimens, only the pileipellis (not the flesh) immediately changes colour to charcoal black. Hyphal system monomitic, all hyphae simple septate, generative hyphae up to $10 \mu \mathrm{m}$ wide. Basidia clavate, with four sterigmata. Basidiospores pale brownish, globose or irregularly subglobose, tuberculate, 

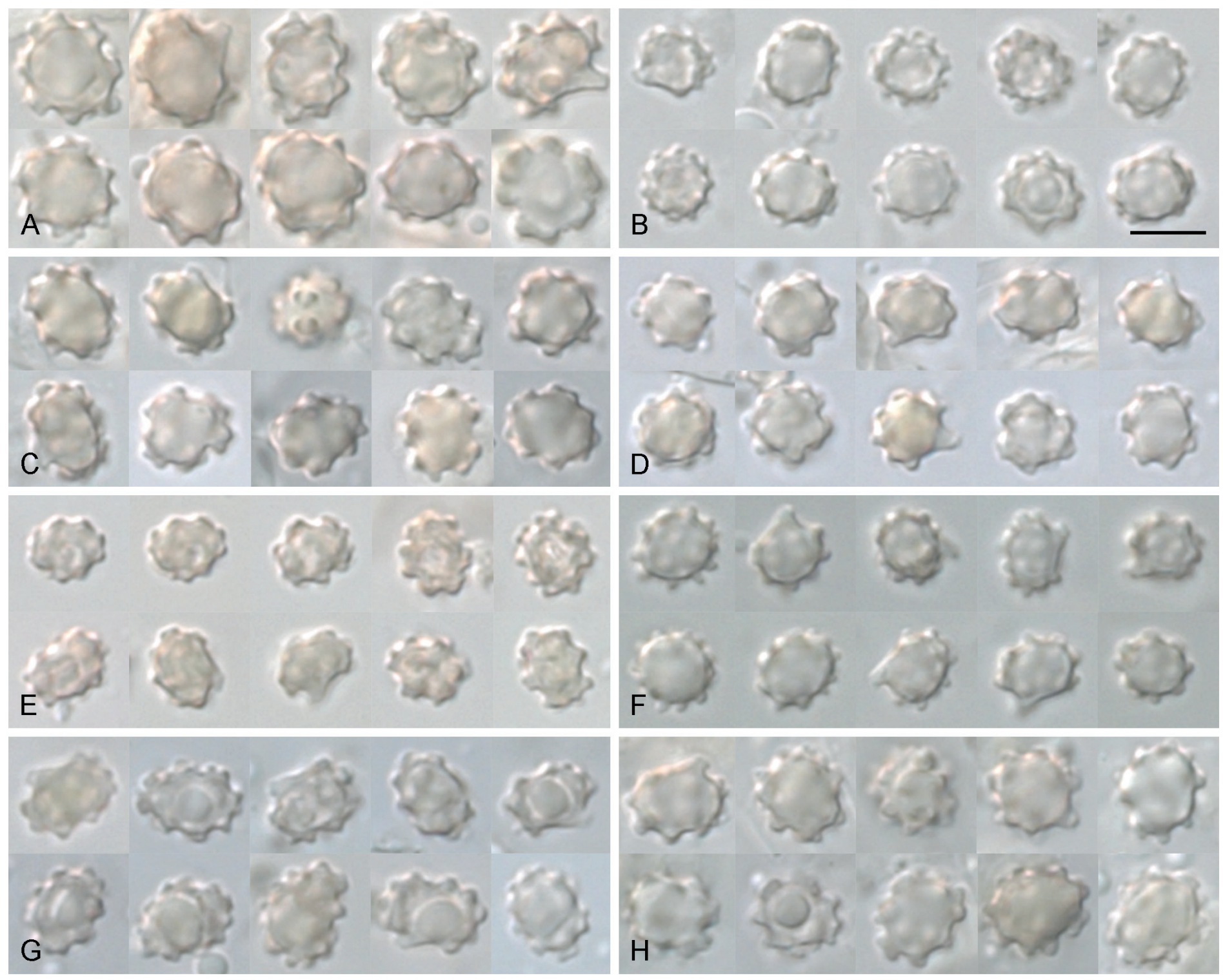

Fig. 9. Hydnellum basidiospores. A. H. fagiscabrosum (holotype, GB-0195805). B. H. glaucopus (GB-0195722). C. H. illudens (GB-0195937). D. H. lepidum (GB-129373). E. H. nemorosum (O-F-242352). F. H. roseoviolaceum (holotype. GB-0195936). G. H. scabrosellum (holotype, GB-0195689). H. H. scabrosum (GB-0195731). Scale bar $=5 \mu \mathrm{m}$.

with oblique apiculus, $5.1-6.6 \times 3.4-4.7 \mu \mathrm{m}$, av. $=5.8 \times 4.0$ $\mu \mathrm{m}, \mathrm{Q}=1.2-1.7(\mathrm{n}=3 / 90$, measurements from the lateral side without tubercles), tubercles numerous, 0.6-0.9 $\mu \mathrm{m}$ high, with prominent, rounded, flattened, flat-topped to exsculpate apices.

Ecology and distribution: Presumably ectomycorrhizal with conifers (mixed forest with Pinus and Picea, associated treespecies not exactly known but probably Pinus sylvestris), strongly calciphilous. Mostly known from coniferous forests situated close to the coast (Gulf of Bothnia) in the province of Gästrikland and northern Uppland, east-central Sweden (at the northern limits of the hemiboreal vegetation zone). This so far Swedish species can be expected to occur in pine forests on calcareous ground around the Baltic Sea.

Additional specimens examined: Sweden, Gästrikland, Hamrånge, Bergby, Näset nat. res., calcareous conifer forest, 15 Sep. 2011, J. Nitare GB-0195807; Uppland, Börstil, Tvärnö, Tuskö, Tuskösundet, 5 Sep. 2008, J. Nitare GB-0195806 (from the same spot as the holotype, fig. 12A in Nitare \& Högberg 2012); Älvkarleby, Lanforsen, Tippön, calcareous Pinus sylvestris forest (with scattered Picea abies), 20 Sep. 2013, G. Aronsson GB-0195791; Askön, calcareous Pinus sylvestris forest (with scattered Picea abies), 13 Sep. 2013, G. Aronsson GB-0195792; Östergötland, Västra Tollstad, Omberg, Ombergsliden nat. res., on soil in calcareous Picea abies forest with Pinus sylvestris and Betula sp., 13 Sep. 2016, E. Larsson GB-0195736.

Notes: Among the hydnoid fungi associated with conifers, Hydnellum scabrosellum is most similar to $H$. scabrosum but has smaller and slenderer basidiomata and looks like a dwarf form of the latter species. The size difference is particularly obvious when considering the stipe diameter which rarely exceeds $1 \mathrm{~cm}$ in $H$. scabrosellum but is usually $2-5 \mathrm{~cm}$ in mature specimens of $H$. scabrosum. The yellowish-ochraceous hymenium and flesh (when dry) and the occurrence on base-rich soil, also differs from the non-calciphilous $H$. scabrosum. The coastal region in Gästrikland, where most collections were made, is characterized by its extremely calcareous-rich soils (moraine), depending on the geological features and recent land uplift during the postglacial period. 


\section{DISCUSSION}

Species in Hydnellum seem to be sensitive to nitrogen deposition and to modern forestry practices (Nitare 2019) and are of conservation concern across Europe. Fewer than 350 fungi are currently included in the IUCN's Red List of threatened species but, already, four European Hydnellum species ( $H$. compactum, $H$. gracilipes, $H$. ioeides and $H$. mirabile) have been assessed as globally Vulnerable (IUCN 2020). In many European countries several species are evaluated as threatened and included on national Red Lists. Furthermore, rich assemblages of Hydnellum and other stipitate hydnoids are increasingly being used in the selection of sites for legal protection and/or habitat-specific conservation management, e.g. in the Netherlands (Ozinga et al. 2013), Sweden (Nitare 2019) and the UK (Bosanquet et al. 2018).

However, conservation assessments and measures require that species definitions are unambiguous and that habitat preferences are reasonably documented. Through the present study and similar earlier studies supported by molecular data, it has become clear that the morphological species concepts used for Hydnellum species in Europe are, in many cases, problematic. Names may cover several species and concepts may also differ between countries, leading to misidentifications. Furthermore, for all the species discussed here it is important to note that basidiomatal morphology and pigments change during development and are also influenced by growth patterns and weather conditions (compare for example the two specimens of $H$. lepidum, Fig. 4G, H). For a safer identification both young and fully developed basidiomata ought to be examined. It is also clear that not enough attention has been paid to host associations. Hydnellum species probably all form ectomycorrhizal partnerships and their host ranges may be more limited than suggested by maps and descriptions found in the literature. Indeed, we recommend that the identification process should always start with careful observation of the habitat and potential ectomycorrhizal partners. If the habitat is a conifer forest, $H$. glaucopus, $H$. illudens and $H$. scabrosum may be present. Hydnellum glaucopus will be found in mesic to moist Picea forest on somewhat base-rich soil while $H$. scabrosum grows in dry pine forest on base-poor, often sandy soil. $H$. illudens probably has a broader habitat choice and seems able to associate with both Picea and Pinus, albeit always on base-rich soil. If, on the other hand, the habitat is a hardwood forest then $H$. fagiscabrosum, $H$. illudens, $H$. nemorosum and $H$. lepidum must be considered during identification. If the habitat is a mixed forest, a morphology-based identification alone may not produce reliable results and DNA sequencing should be considered.

Maas Geesteranus (1971, 1975a) introduced section Scabrosi (under Sarcodon) and included S. scabrosus (section type), S. fennicus, S. glaucopus, S. lepidus and S. regalis. Commenting on a key to the section, Maas Geesteranus (1975a) wrote "Die Unterscheidung bereitet öfters Schwierigkeiten!". Sarcodon illudens was a later addition (Maas Geesteranus 1976) and in the present paper three new species, $H$. fagiscabrosum, $H$. nemorosum, and $H$. scabrosellum, add further complexity to the section. Furthermore, sequences from specimens identified as $S$. cyrneus and $H$. underwoodii were also recovered within section Scabrosi. If these sequences are correctly named, the placement is at odds with that of Maas Geesteranus (1971, 1975a) who referred both species to his section Squamiceps.
Section Squamiceps was distinguished from section Scabrosi by its lack of a blue-green stipe base and context (Maas Geesteranus 1975a). Our sequences of two Italian collections initially identified as $S$. cyrneus were either left as named (K(M)197488) in the absence of an appropriate reference sequence, or redetermined as $H$. illudens (K(M)197492). However, our molecular evidence indicates that both collections belong in section Scabrosi. They would therefore be expected to have the characteristic blue-green stipe pigmentation, which is contrary to the original description of S. cyrneus. Indeed, in Sardinia at least, some morphological interpretations of $S$. cyrneus can include specimens with blue flesh at the base of the stipe (Brotzu 1998). We cannot be sure whether the terminal cluster comprising K(M)197488 and the GenBank sequence (MH681180) derived from an Italian ectomycorrhizal root tip of Quercus pubescens (Fig. 3) represents S. cyrneus sensu typi or yet another undescribed species. Further study of collections morphologically identified as S. cyrneus is urgently needed.

With the exception of Hydnellum glaucopus, phylogenetic analyses support the validity of section Scabrosi sensu Maas Geesteranus. Hydnellum glaucopus is here recovered as a member of section Violacei. Hydnellum glaucopus and $H$. scabrosum, the type of section Scabrosi, are often confounded. Maas Geesteranus (1975a: 65) was aware of the problem and, commenting on the description of $H$. glaucopus, he concluded "Es gehört Erfahrung dazu, um vorliegende Art von dem vielgestaltigen S. scabrosus zu unterschieden". The confusion partly stems from the failure to recognize scabrosum-like specimens growing with Fagaceae as a separate species. Such specimens have mostly been considered to be the true $H$. scabrosum while similar-looking specimens collected in conifer forests have, to some extent, been named $H$. glaucopus. The latter species is, however, morphologically distinguishable since it has a subtomentose to somewhat glossy pileal surface that is smooth or with age rupturing in the centre to expose the paler flesh. The pileal colour is greyish brown with rosy or violet tints and it darkens where touched or damaged to dark chocolate brown.

In our phylogenetic ITS analyses of section Violacei (Fig. 2), a sequence identified as Sarcodon calvatus (UNITE UDB024867) and generated from a basidioma from British Columbia, Canada, showed $99.2 \%$ similarity to European Hydnellum glaucopus. If it can be shown that this specimen is identical to the type from Oregon, USA, then the older name $S$. calvatus takes precedence over $H$. glaucopus. However, S. calvatus has, according to the protologue (Harrison 1964), clamps at the basidial bases while in $H$. glaucopus basidial bases and other septa are clampless. Thus, we find it less likely that these two species are synonyms.

We sequenced the holotypes of Hydnellum glaucopus, $H$. illudens and $H$. lepidum; an isotype of Sarcodon regalis and the neotype of $H$. scabrosum (see Table 1 for further details). The results show that $H$. lepidum and $S$. regalis are conspecific. They were initially described in the same publication (Maas Geesteranus 1975a) and so it would seem that although Sarcodon lepidus was presented first, both names have equal priority. However, although a holotype was designated for $S$. lepidus, this did not occur for S. regalis (or for S. cyrneus) and the name was not validly published. The oversight was soon corrected by the designation of a lectotype (correctable to holotype) and the name (and that of S. cyrneus) was validated in Maas Geesteranus (1975b). Hence S. regalis becomes a synonym of Hydnellum lepidum. 
Hydnellum scabrosum was not supported in the present analyses. Its coherence should preferably be studied through an analysis including additional genetic regions. Such an analysis might also be useful in addressing the phylogenetic relationships within Hydnellum - an interesting and as yet unresolved topic which lay outside the scope of the current study.

Maas Geesteranus (1975a) reported the American species Hydnellum underwoodii from Europe and referred some Dutch collections to this name (as Sarcodon). Sequences from several American specimens identified as $S$. underwoodii were published by Baird et al. (2013). These sequences form a separate clade within section Scabrosi and any similar sequence has so far not been detected from Europe. We sequenced one Dutch specimen named S. underwoodii and it turned out to be $H$. lepidum. Whether true $H$. underwoodii is growing in Europe remains unclear.

Through this study future conservation prioritisation, planning and action will be underpinned by a more solid scientific foundation, particularly in central and northern European countries, the main focus of our sampling thus far. Needless to say, reports in the literature and in public databases using any of the names discussed here and not supported by sequence information, must be regarded with caution. When a voucher is available, it might be possible to revise the identification. However, all observations without a voucher, which are now being increasingly reported to biodiversity databases and further spread through meta-databases like GBIF, cannot be trusted and we warn against any uncritical usage of such data in checklist compilations and red-listing evaluations.

\section{ACKNOWLEDGEMENTS}

We thank the many Swedish, Norwegian, Danish, British, Dutch, Italian and Spanish mycologists who provided us with collections, either directly or through their depositions in nationally recognized fungaria, including all those who are named in Table 1. The staff at the fungaria in Uppsala and Leiden are acknowledged for help during our visits. We thank Gillis Aronsson for continuous support and for his contribution to revealing the new species Hydnellum scabrosellum. We also thank Bryn Dentinger (Univ. Utah) for generating and providing the ITS sequence from $S$. regalis (K(M)38542), Kare Liimatainen (RBG Kew) for the sequence from H. ioeides (K(M)236333), Beatrice Senn-Irlet (Swiss Fed. Res. Inst.) for the sequence from $H$. illudens (ZT-Myc-64129) and Paul M. Kirk (RBG Kew) for nomenclatural advice on $S$. regalis. Generous financial support was provided to Ellen Larsson by The Swedish Taxonomy Initiative (Artdatabanken 2014-152 4.3) and to Karl-Henrik Larsson by The Norwegian Taxonomy Initiative (ArtsDatabanken ADB54-09). Natural England (Species Recovery Programme) and Plantlife International are acknowledged for financial support provided to Martyn Ainsworth and to a series of stipitate hydnoid survey/sequencing projects (20092013) and the following are thanked for their valuable support for, and input to, these projects: Lynne Boddy \& Hilary Rogers (Cardiff Univ.), Ted Green \& Crown Estate staff (Windsor), Alan Lucas \& FCE staff (New Forest) and Stewart Taylor \& RSPB staff (Abernethy).

Conflict of interest: The authors declare that there is no conflict of interest.

\section{REFERENCES}

Ainsworth AM, Parfitt D, Rogers HJ, et al. (2010). Cryptic taxa within European species of Hydnellum and Phellodon revealed by combined molecular and morphological analysis. Fungal Ecology 3: 65-80.

Arnolds E (2003). De stekelzwammen en pruikzwammen van Nederland en België. Coolia 46(3) supplement: 1-96.

Arnolds E (2010). The fate of hydnoid fungi in The Netherlands and Northwestern Europe. Fungal Ecology 3: 81-88.

Ayres DL, Darling A, Zwickl DJ, et al. (2012). BEAGLE: an application programming interface and high-performance computing library for statistical phylogenetics. Systematic Biology 61: 170-173.

Baird R, Wallace LE, Baker G, et al. (2013). Stipitate hydnoid fungi of the temperate southeastern United States. Fungal Diversity 62: 41-114.

Bidartondo MI, Bruns TD (2001). Extreme specificity in epiparasitic Monotropoideae (Ericaceae): widespread phylogenetic and geographical structure. Molecular Ecology 10: 2285-2295.

Bosanquet SDS, Ainsworth AM, Cooch SP, et al. (2018). Guidelines for the selection of Biological SSSIs. Part 2: Detailed guidelines for habitats and species groups. Chapter 14 Nonlichenised Fungi. Joint Nature Conservation Committee, UK. https://hub.jncc.gov.uk/ assets/d1fcb171-8086-4f5b-ade5-a34c5edc78c5.

Breitenbach J, Kränzlin F (1986). Fungi of Switzerland vol. 2. Verlag Mykologia, Switzerland.

Brock PM, Döring H, Bidartondo MI (2009). How to know unknown fungi: the role of a herbarium. New Phytologist 181: 719-724.

Brotzu R (1998). Funghi della Sardegna. II Maestrale, Italy.

Chernomor O, von Haeseler A, Minh BQ (2016). Terrace aware data structure for phylogenomic inference from supermatrices. Systematic Biology 65: 997-1008.

Dentinger BTM, Margaritescu S, Moncalvo J-M (2010). Rapid and reliable high-throughput methods of DNA extraction for use in barcoding and molecular systematics of mushrooms. Molecular Ecology Resources 10: 628-633.

Fries EM (1836). Anteckningar öfver de i Sverige växande ätliga svampar. (Part 8). Palmblad, Sebell \& C., Sweden.

Fries EM (1874). Hymenomycetes Europaei. Upsaliae, Ed. Berling, Sweden.

Gardes M, Bruns TD (1993). ITS primers with enhanced specificity for basidiomycetes - application to the identification of mycorrhizae and rusts. Molecular Ecology 2: 113-118.

Guindon S, Dufayard J-F, Lefort V, et al. (2010). New algorithms and methods to estimate maximum-likelihood phylogenies: Assessing the performance of PhyML 3.0. Systematic Biology 59: 307-321.

Gulden G, Hanssen EW (1992). Distribution and ecology of stipitate hydnaceous fungi in Norway, with special reference to the question of decline. Sommerfeltia 13: 1-58.

Harrison KA (1961). The stipitate hydnums of Nova Scotia. Canada Dept. of Agriculture (Publ. 1099), Canada.

Harrison KA (1964). New or little known North American stipitate hydnums. Canadian Journal of Botany 42: 1205-1233.

Harrison KA, Grund DW (1987). Preliminary keys to the terrestrial stipitate hydnums of North America. Mycotaxon 28: 419-426.

Hoang DT, Chernomor O, von Haeseler A, et al. (2018). UFBoot2: Improving the ultrafast bootstrap approximation. Molecular Biology and Evolution 35: 518-522.

Holec J, Kučera T (2018). Hydnoid fungi of the family Bankeraceae their assemblages and vegetation ecology in Central Europe, Czech Republic. Fungal Ecology 32: 40-48.

Hopple Jr JS, Vilgalys R (1999). Phylogenetic relationships in the mushroom genus Coprinus and dark-spored allies based on 
sequence data from the nuclear gene coding for the large ribosomal subunit RNA: divergent domains, outgroups, and monophyly. Molecular Phylogenetics and Evolution 13: 1-19.

Hrouda P (1999). Hydnaceous fungi of the Czech Republic and Slovakia. Czech Mycology 51: 99-155.

Hughes KW, Petersen RH, Lickey EB (2009). Using heterozygosity to estimate a percentage DNA sequence similarity for environmental species' delimitation across basidiomycete fungi. New Phytologist 182: 795-798.

IUCN (2020). IUCN Red List of threatened species. https://www. iucnredlist.org/ accessed 06 Oct. 2020.

Kalyaanamoorthy S, Minh BQ, Wong TKF, et al. (2017). ModelFinder: Fast model selection for accurate phylogenetic estimates. Nature Methods 14: 587-589.

Kranabetter JM, Stoehr M, O'Neill GA (2015). Ectomycorrhizal fungal maladaptation and growth reductions associated with assisted migration of Douglas-fir. New Phytologist 206: 1135-1144.

Larsson A (2014). AliView: a fast and lightweight alignment viewer and editor for large datasets. Bioinformatics 30: 3276-3278.

Larsson E, Jacobsson S (2004). Controversy over Hygrophorus cossus settled using ITS sequence data from 200 year-old type material. Mycological Research 108: 781-786.

Larsson K-H, Svantesson S, Miscevic D, et al. (2019). Reassessment of the generic limits for Hydnellum and Sarcodon (Thelephorales, Basidiomycota). MycoKeys 54: 31-47.

Lian C, Narimatsu M, Nara K, et al. (2006). Tricholoma matsutake in a natural Pinus densiflora forest: correspondence between aboveand below-ground genets, association with multiple host trees and alteration of existing ectomycorrhizal communities. New Phytologist 171: 825-836.

Loizides M, Alvarado P, Assyov B, et al. (2016). Hydnellum dianthifolium sp. nov. (Basidiomycota, Thelephorales), a new tooth-fungus from southern Europe with notes on $\mathrm{H}$. concrescens and $\mathrm{H}$. scrobiculatum. Phytotaxa 280: 23-35.

Maas Geesteranus RA (1956). The stipitate hydnums of the Netherlands I. Sarcodon P. Karst. Fungus 26: 44-60.

Maas Geesteranus RA (1971). Hydnaceous fungi of the eastern old world. Verhandelingen der Koninklijke Nederlandse Akademie van Wetenschappen, Afdeling Natuurkunde Tweede Reeks 60: 1-176.

Maas Geesteranus RA (1975a). Die terrestrischen Stachelpilze Europas [The terrestrial hydnums of Europe]. Verhandelingen der Koninklijke Nederlandse Akademie van Wetenschappen, Afdeling Natuurkunde Tweede Reeks 65: 1-127.

Maas Geesteranus RA (1975b). Corrections. Persoonia 8: 166.

Maas Geesteranus RA (1976). Notes on hydnums. X. Proceedings van de Koninklijke Nederlandse Akademie van Wetenschappen Ser. C. 79: 273-289.

Maas Geesteranus RA, Nannfeldt JA (1969). The genus Sarcodon in Sweden in the light of recent investigations. Svensk Botanisk Tidskrift 63: 401-440.

Miller MA, Pfeiffer W, Schwartz T (2010). Creating the CIPRES Science Gateway for inference of large phylogenetic trees. 2010 Gateway Computing Environments Workshop (GCE), New Orleans, LA: 1-8. https://doi.org/10.1109/GCE.2010.5676129.

Moeller HV, Peay KG, Fukami T (2014). Ectomycorrhizal fungal traits reflect environmental conditions along a coastal California edaphic gradient. FEMS Microbiology Ecology 87: 797-806.

Nguyen L-T, Schmidt HA, von Haeseler A, et al. (2015). IQ-TREE: A fast and effective stochastic algorithm for estimating maximum-likelihood phylogenies. Molecular Biology and Evolution 32: 268-274.
Nilsson RH, Larsson K-H, Taylor AFS, et al. (2018). The UNITE database for molecular identification of fungi: handling dark taxa and parallel taxonomic classifications. Nucleic Acids Research 47: D259-D264.

Nitare J (2006). Åtgärdsprogram för bevarande av rödlistade fjälltaggsvampar (Sarcodon) [Action plan for red-listed species of Sarcodon in Sweden]. Naturvårdsverket, Rapport 5609, Sweden.

Nitare J (2019). Skyddsvärd skog. Naturvårdsarter och andra kriterier för naturvärdesbedömning [Woodland nature conservation indicator species and other criteria for assessing the protection value of woodland sites]. Skogsstyrelsen, Sweden.

Nitare J, Högberg N (2012). Svenska arter av fjälltaggsvampar (Sarcodon) - en preliminär rapport [The genus Sarcodon in Sweden - a preliminary report]. Svensk Mykologisk Tidskrift 33: 2-49.

Nylander JAA (2004). MrModeltest v2. Program distributed by the author. Evolutionary Biology Centre, Uppsala University, Sweden.

Ozinga WA, Arnolds E, Keizer P-J, et al. (2013). Paddenstoelen in het natuurbeheer: $O B N$ preadvies paddenstoelen [Macrofungi in conservation management. OBN report]. Ministry of Economic Affairs, the Netherlands.

Parfitt D, Ainsworth AM, Simpson D, et al. (2007). Molecular and morphological discrimination of stipitate hydnoids in the genera Hydnellum and Phellodon. Mycological Research 111: 761-777.

Pegler DN, Roberts PJ, Spooner BM (1997). British chanterelles and tooth fungi. RBG Kew, UK.

Phillips R (1981). Mushrooms and other fungi of Great Britain \& Europe. Pan, UK.

Rasmussen AL, Busby RR, Hoeksema JD (2018). Host preference of ectomycorrhizal fungi in mixed pine-oak woodlands. Canadian Journal of Forest Research 48: 153-159.

Ronquist $F$, Teslenko $M$, van der Mark $P$, et al. (2012). MrBayes 3.2: Efficient Bayesian phylogenetic inference and model choice across a large model space. Systematic Biology 61: 539-542.

Runnel K, Põldmaa K, Lõhmus A (2014). 'Old-forest fungi' are not always what they seem: the case of Antrodia crassa. Fungal Ecology 9: 27-33.

Smith JH, Suz LM, Ainsworth AM (2016). Red List of Fungi for Great Britain: Bankeraceae, Cantharellaceae, Geastraceae, Hericiaceae and selected genera of Agaricaceae (Battarrea, Bovista, Lycoperdon \& Tulostoma) and Fomitopsidaceae (Piptoporus). http://fungi. myspecies.info/content/conservation.

Stalpers JA (1993). The Aphyllophoraceous fungi l: keys to the species of the Thelephorales. Studies in Mycology 35: 1-168.

Strandberg M, Borgen T (2020). Records of Sarcodon regalis sensu Strandberg \& Borgen in Danmarks svampeatlas (Atlas of Danish fungi). https://svampe.databasen.org/ accessed 08 May 2020.

Suz LM, Barsoum N, Benham S, et al. (2014). Environmental drivers of ectomycorrhizal communities in Europe's temperate oak forests. Molecular Ecology 23: 5628-5644.

Trifinopoulos J, Nguyen L-T, von Haeseler A, et al. (2016). W-IQ-TREE: a fast online phylogenetic tool for maximum likelihood analysis. Nucleic Acids Research 44: W232-W235.

van der Linde S, Alexander I, Anderson IC (2008). A PCR-based method for detecting the mycelia of stipitate hydnoid fungi in soil. Journal of Microbiological Methods 75: 40-46

White TJ, Bruns T, Lee S, et al. (1990). Amplification and direct sequencing of fungal ribosomal RNA genes for phylogenetics. In: PCR protocols: A guide to methods and applications (Innis MA, Gelfand DH, Sinisky JJ, et al., eds). Academic Press, USA: 315-322. 